\title{
Guardians of Democracy or Passive Bystanders? A Conjoint Experiment on Elite Transgressions of Democratic Norms
}

\author{
THE FINAL VERSION OF THIS PREPRINT WAS PUBLISHED IN POLITICAL \\ RESEARCH QUARTERLY: https://doi.org/10.1177\%2F10659129211073592
}

\author{
Inga A.-L. Saikkonen ${ }^{1}$ inga.saikkonen@abo.fi \\ Social Science Research Institute and the Department of Political Science \\ Åbo Akademi University \\ ORCID: 0000-0003-2303-0328
Henrik Serup Christensen henrik.christensen@abo.fi
Department of Political Science
Åbo Akademi University
ORCID: 0000-0003-2916-0561

Preprint date: 31 December 2021

\begin{abstract}
Emerging literature shows that citizens in established democracies do not unconditionally support central democratic principles when asked to weigh them against copartisanship or favored policy positions. However, these studies are conducted in highly polarized contexts, and it remains unclear whether the underlying mechanisms also operate in more consensual contexts. Furthermore, it is unclear whether 'critical citizens' or satisfied democrats are more eager to support democratic principles. We study these questions with evidence from a conjoint experiment conducted in Finland ( $n=1030)$, an established democracy with high levels of democratic satisfaction and a consensual political culture. We examine how transgressions of two central democratic norms, the legitimacy of political opposition and the independence of the judiciary, affect leader favorability. We also explore how these differ across ideological and policy congruence, and across levels of political disaffection. Our results show that segments of the Finnish population are willing to condone authoritarian behavior if this brings them political benefits. Furthermore, we find that satisfied rather than 'critical' citizens are more likely to sanction such behavior. These findings suggest that dangers of democratic deconsolidation may appear even in consensus democracies with relatively low levels of political polarization.
\end{abstract}

Key words: democratic deconsolidation, democratic transgressions, political dissatisfaction, policy congruence, conjoint experiments

Funding: This research was funded by the Academy of Finland (Grant 285167 and Grant 316897).

\footnotetext{
${ }^{1}$ Both authors have contributed equally to this article.
} 


\section{Introduction}

Public support for democracy is essential for democratic stability (Dahl 1956, Lipset 1959, Easton 1965). Recent scholarship has debated whether voters in established democracies are increasingly willing to support more authoritarian political alternatives to democracy, but the findings are very mixed (Foa and Mounk 2016, 2017 vs. Alexander and Welzel 2017, Norris 2017, Voeten 2017). Most recent studies have concluded that even though voters in established democracies are very critical on how democracy functions in their countries, they are still supportive of core democratic principles and continue to endorse democracy as a political system (Norris 1999, 2017, Wuttke et al. 2020).

Yet, democratic stability also requires that people are willing to translate their pro-democratic attitudes into practice, by being willing to defend democracy against the transgressions of political leaders (Weingast 1997, 2005, Fearon 2011, for a discussion, see also Luo and Przeworski 2019). Indeed, classical liberal democratic theory stresses the need for citizen vigilance against "the potential abuse of power by the state" (Norris 2011, 245). Alarmed by the rise of populist and authoritarian politicians in the world an emerging line of scholarship has begun to examine whether citizens in established democracies are willing to condemn democratic transgressions by politicians, especially when this means prioritizing democratic principles against favored policy goals or co-partisanship (Carey et al. 2020, Graham and Svolik 2020). Most prominently, Graham and Svolik (2020) found that when voters are asked to weigh their support for democratic principles against partisan interests or policy concerns, they care more about them than democratic norms (for more nuanced findings, see Carey et al. 2020). These findings are in line with earlier studies that have shown that citizens take into consideration multiple issue areas when evaluating the conduct of politicians, and do not always punish 'malfeasant' politicians if supporting these politicians brings adjacent benefits (Klašnja and Tucker 2013, Franchino and Zucchini 2015, Breitenstein 2019, see also Singer 2018). 
We contribute to both literatures with the help of data from a conjoint survey experiment embedded in a nationally representative survey carried out in Finland in May and June 2020. First, building on Carey et al. (2020) and Graham and Svolik (2020), we examine whether Finnish citizens support core democratic principles, especially when they are asked to weigh them against other important dimensions, such as ideological or policy congruence. Conjoint experiments are particularly suited for exploring these questions as they enable us to probe respondents' attitudes towards democracy while avoiding problems with social desirability bias that may affect answers to direct survey questions (Hainmueller et al. 2014, Svolik 2019 and 2020). Moreover, the experimental design allows us to explore the multidimensional choices that citizens make when assessing the behavior of (un)democratic politicians and allows us to probe citizens' 'actual' commitment to democratic values as opposed to their 'stated' preferences measured in comparative surveys (see Svolik 2019 and 2020, Graham and Svolik 2020).

Our results show that most Finnish citizens continue to support core principles of democracy. However, worryingly, we also find that even in Finland, with high levels of democratic satisfaction (Rapeli and Koskimaa 2020) and a consensual political culture (Karvonen 2014), some people are willing to ignore blatant transgressions of democratic principles when there is ideological and policy goal alignment. The extant literature on voters' reactions to democratic transgressions has examined these 'trade-off effects' mostly in highly politically polarized contexts, such as the US and Venezuela (Carey et al. 2020, Graham and Svolik 2020, Svolik 2020). These studies have suggested that individual-level political polarization is partially driving the unwillingness of voters to condemn democratic norm violations by politicians (McCoy and Somer 2019, Svolik 2019 and 2020, Graham and Svolik 2020). Our empirical setting allows us to examine voter reactions to democratic norm violations by politicians in a polity characterized by high degrees of social trust (Söderlund 2019) and relatively low ideological and affective polarization (Isotalo et al. 2020, Reiljan 2020, Wagner 2021). Yet we find that segments of the Finnish population are willing to make significant trade-offs between democratic principles and policy concerns. This suggests that 
these concerns may not be purely driven by political polarization but may be more general to political behavior in established democracies.

We also examine differences across levels of political disaffection and thus contribute to the debate on the linkage between democratic disaffection and support for democracy. To our knowledge, this has not been examined with experimental evidence previously. We find that citizens with higher levels of political trust and democratic satisfaction are more likely to defend core democratic principles. This suggests that citizens with high political satisfaction rather than the 'critical citizens' (see Norris 1999) are the true guardians of democracy.

\section{Theoretical expectations: Citizens and democratic transgressions}

Democracy is a multi-dimensional concept. Mettler and Lieberman (2020) argue that the functioning of modern representative democracy is based on four essential dimensions: free and fair elections, respecting civil and political rights of the population, respecting the legitimacy of the political opposition, and respecting the system of separation of powers and the rule of law. The latter two dimensions, respecting the legitimacy of political opposition and respecting the independence of the judiciary, have been especially under attack in many European established democracies, and we therefore focus on measuring citizen responses to the trampling of these two key democratic norms.

First, we examine citizens' reactions to politicians breaking the democratic norm of respecting the legitimacy of the political opposition. Modern representative democracy is based on free competition between politicians for the support of the voters (Schumpeter 1942). The functioning of representative democracy thus entails that politicians respect the legitimacy of their political opponents and do not prevent each other from governing or campaigning (Levitsky and Ziblatt 2018, Mettler and Lieberman 2020). Building on the work of Juan Linz (1978) Levitsky and Ziblatt (2018) argued that toleration for or encouragement of violence 
against political opposition are warning signs that can help to identify politicians with authoritarian tendencies. We first examine how Finnish citizens react to politicians seeking to restrict political competition by exhorting the use of political violence against their opponents. The literature on social norms and informal institutions suggests that citizens should punish transgressions of 'socially shared norms' such as basic democratic principles (Helmke and Levitsky 2004). Finnish voters report one of the highest levels of democratic satisfaction in Europe, and the level of satisfaction has remained rather stable over time (Karvonen, 2014; Kestilä-Kekkonen 2015, Rapeli and Koskimaa 2020). Overall, we expect Finnish citizens to condemn the exhortation of the use of political violence against their opponents.

However, we go beyond previous efforts by examining how leader favorability is affected when leaders transgress this basic democratic norm by either inciting violence or failing to condemn this sort of violence when it does occur. Unlike previous studies that have studied voter reactions to politicians either supporting or opposing democratic violations, our experiment includes cases where politicians tacitly approve serious democratic violations. This resembles real-world behavior where politicians with authoritarian tendencies rarely advocate illicit actions directly. Instead, they often signal their support for these actions by refraining from explicitly condemning these practices. While violence in any form clearly violates basic democratic norms, there is a subtle, albeit important, difference between a leader manifestly inciting violence and quietly failing to clearly denounce it when it does occur. From a democratic perspective, citizens should be able to recognize that both tacitly approving violence and inciting violence constitute violations of the basic democratic credo. However, there may nonetheless be important differences in how they affect leader favorability, which it is important to examine.

The other basic democratic principle that we examine concerns the rule of law and the respect for the separation of powers. Democracy entails the basic legal and political equality of all the citizens (Dahl 1991) and therefore the rule of law is one of the 'essential pillars' of democratic 
regimes (O’Donnell 2004, 32). However, questioning the legitimacy of judicial decisions and judicial independence has become worryingly common even in many established European democracies. Breaking the norm of judicial deference also "frequently signal[s] the early stages of democratic erosion" (Helmke and Rosenbluth 2009, Mounk 2018, cited in Carey et al. 2020, 4). The second norm that we test therefore is politician's judicial deference to court decisions, and whether politicians argue that judicial decisions should be respected even though this may be politically disadvantageous for their party. Previous research has found that voters punish politicians breaking the norm of judicial deference when there is a strong pre-existing norm of compliance with the courts (Krehbiel 2020), as there is in Finland (Kestilä-Kekkonen 2015). We should therefore expect Finnish respondents to condemn this democratic transgression.

In our conjoint experiment, we examine how breaking these two basic democratic norms, not condemning or inciting violence against political opponents and not respecting judicial independence, affects the favorability of hypothetical political leaders. We expect that, overall, Finnish citizens will condemn these democratic transgressions. Accordingly, we propose the following two hypotheses for the direct effects of leader transgressions of basic democratic norms:

H1a: Not condemning or inciting physical attacks against opposition candidates have negative effects on favorability compared to condemning violence against opposition candidates

H1b: Disrespecting the decisions of judicial officials has a negative effect on favorability compared to respecting the decisions of judicial officials

However, these effects may not be homogenous in the population. Particularly relevant issues for the current purposes are the extent to which ideological or policy congruence moderates these effects (see Graham and Svolik 2020). Citizens evaluate politicians based on a multiple, sometimes conflicting issues areas, such as their policy positions and their reputation for 
competence (valence) (Franchino and Zucchini 2015). Moreover, citizens are found to make trade-offs between these various dimensions when they evaluate the favorability of different politicians (Franchino and Zucchini 2015, Breitenstein 2019, Graham and Svolik 2020). For example, voters may care sincerely about combating corruption, but are willing to overlook corrupt behavior by politicians if they represent qualities that are otherwise desirable for voters (Breitenstein 2019, see also Klašnja and Tucker 2013). For the present purposes, previous literature has found that voters' willingness to punish politicians who violate democratic standards is moderated by their policy preferences. Voters with intense policy preferences have been found to put more weight on strongly held policies than on democratic norms (Graham and Svolik 2020). We therefore expect that Finnish respondents are less willing to condemn democratic violations by leaders who represent the 'same side' in a policy position that is important to the respondents.

Based on these considerations, we propose the following hypotheses for how the effects of norm transgressions may differ depending on policy congruence: ${ }^{\mathrm{i}}$

H2a: The effects of not condemning or inciting physical attacks against opposition candidates are weaker when the leader's policy position is congruent with the respondent's policy position.

H2b: The effects of disrespecting the decisions of judicial officials are weaker when the leader's policy position is congruent with the respondent's policy position.

Voters have also been found to make trade-offs between partisanship and other attributes of politicians (Breitenstein 2019) and this may even crowd out other relevant information (Kirkland and Coppock 2018). The extant literature has found that partisanship moderates voters' willingness to punish democratic violations by politicians. Voters employ a partisan 'double standard' when reacting to politicians' democratic violations, thus punishing politicians 
with different partisanship more strongly than co-partisan politicians (Graham and Svolik 2020). While ideology and partisanship remain intertwined, partisanship may be less imperative in multiparty systems, especially in Finland where the electoral system is strongly candidatecentered (Borg et al. 2020) and affective polarization has traditionally been low, even if it has increased slightly in recent years (Isotalo et al. 2020). However, some studies have found that ideological congruence may play a similar role in moderating voters' willingness to condemn politicians who transgress against basic democratic norms (Singer 2018, Chiopris et al. 2021). This is especially the case for egocentric ideological congruence, where there is a close ideological match between the individual and the executive (Mayne and Hakhverdian 2016). Singer (2018) suggests that citizens who see the sitting executive as a representative of their ideological interests are more willing to accept authoritarian behavior from political leaders. This suggests that citizens may be willing to trade off ideological congruence for democratic principles, that is, overlook democratic transgressions committed by a leader who is ideologically close to them. Based on these considerations, we propose the following hypotheses for ideological congruence:

H3a: The effects of not condemning or inciting physical attacks against opposition candidates are weaker when the leader's ideological position is congruent with the respondent's ideological position.

H3b: The effects of disrespecting the decisions of judicial officials are weaker when the leader's ideological position is congruent with the respondent's ideological position.

A major factor for explaining the increased tolerance for transgression of basic democratic norms is related to the increase in political disaffection. Political disaffection is a multifaceted phenomenon witnessed in most democratic countries, which entails that populations experience low levels of trust in political actors and institutions, decreasing satisfaction with the functioning of the democratic system, and a dwindling belief in the responsiveness of the 
political system (Norris 2011, Stoker 2006). The increase in political disaffection seems to be connected to the increasing political incivility that shapes the nature of contemporary politics and is particularly prevalent among populist leaders who challenge the status quo (Mutz 2015, Sydnor 2019). Populist leaders frequently exploit feelings of discontent by questioning the legitimacy of liberal democracy and the elected officials (Norris and Inglehart 2019, 4-6). It is therefore important to examine whether the effects of transgressions differ across levels of political disaffection to understand why some citizens may be willing to accept that leaders transgress basic democratic norms.

Political attitudes of ordinary citizens have to some extent been neglected in the literature on democratic backsliding. For example, Levitsky and Ziblatt (2018) discuss various informal norms that act as guardrails to protect democracy, but focus exclusively on political elites and institutional factors. Nevertheless, citizens may also act like guardians of democracy by punishing democratic transgressions of elites (see, e.g. Weingast 1997). Classical literature on democratic support argued that the satisfaction of citizens was paramount for democratic stability (Almond and Verba 1963, Easton 1965). According to this line of reasoning, it is the satisfied citizens who are likely to punish leaders who violate democratic norms. However, more recent contributions argue that that critical political attitudes may be beneficial for democracy. Indeed, disaffection does not necessarily entail a rejection of democracy per se, but a negative evaluation of the actual performance of democracy (Norris and Inglehart 2017, 427). According to Inglehart (1997), generations born after WW2 exhibit more critical attitudes toward authorities, including political elites. However, this does not entail that they reject democracy as an ideal. On the contrary, people embrace democratic ideals but reject traditional forms of participation and dislike the functioning of the traditional representative structures since they feel that these do not constitute a genuine democracy. According to this perspective, people may be dissatisfied with the performance of the traditional democracy, but these 
sentiments are beneficial for democracy since their critical attitudes keep citizens alert and decision makers accountable (Norris 1999). It may therefore be the case that critical citizens are more disapproving of democratic transgressions. Nevertheless, our hypotheses here follow the traditional view that disaffection enhances toleration for transgressions. We test the following hypotheses for the effects across levels of political disaffection:

H4a: The effects of not condemning or inciting physical attacks against opposition candidates are weaker among respondents with high levels of political disaffection

H4b: The effects of disrespecting judicial officials are weaker among respondents with high levels of political disaffection

Since political disaffection is a multifaceted phenomenon with different important aspects, we examine these differences by focusing on three different attitudes: Political trust, satisfaction with democracy, and external political efficacy. These attitudes provide an extensive overview of different types of disaffection, even if the selection is not exhaustive.

\section{A conjoint analysis of elite transgressions}

Conjoint analysis has become a popular tool within political science since it offers a way to test multidimensional causal relations for a variety of purposes including candidate choice, policy evaluations and participatory mechanisms (Hainmueller et al. 2014, Franchino and Zucchini 2015, Christensen 2020, Kirkland and Coppock 2018, Breitenstein 2019). In a conjoint analysis, respondents evaluate sets of alternatives with randomly varied attributes (Hainmueller et al. 2014). The attributes are the characteristics assumed to affect evaluations and the levels are discrete categories describing theoretically relevant values of the attribute in question. Although such experimental approaches potentially suffer from a lack of external validity, a study comparing effects from survey experiments with a natural experiment showed that the 
hypothetical scenarios did remarkably well in predicting real-life effects (Hainmueller, Hangartner and Yamamoto 2015).

The use of conjoint analysis is warranted for the present purpose (Hainmueller et al. 2014). It is possible to examine the effects of multiple traits on evaluations, meaning we can assess differences between the impacts of democratic transgressions and compare effects to other potential attributes. The conjoint design mimics the situation that voters face in elections where they are choosing between several candidates (Mares and Young 2019, Graham and Svolik 2020). This increases the face validity of the conjoint experiment, especially in Finland where the electoral system entails that voters are accustomed to choosing between candidates rather than parties (Christensen et al. 2020). Conjoint analysis also makes it possible to limit problems with social desirability bias, which often present a challenge when examining sensitive questions in surveys, including biases against female candidates (Ono and Yamada 2018), or voting for corrupt candidates (Breitenstein 2019). Since it is not necessary to ask respondents directly for their preferences on the given attributes, it is more likely that they will answer truthfully. Finally, conjoint analysis also makes it possible to assess differences across subgroups in the population (Hainmueller et al., 2014), which is a central part of the current endeavors.

In the choice-based conjoint design used here, respondents were presented with comparisons of two profiles presented as prospective prime ministers and were asked to pick the profile they would prefer as prime minister of Finland. ${ }^{\text {ii }}$ Since we are here interested in the factors shaping citizens' general evaluations of Finnish political elites and their actions, we did not construe the comparison as a voting decision, as is often the case in the literature (Breitenstein 2019, Christensen et al. 2020, Kirkland and Coppock 2018). We did, however, ask a follow-up question whether people would also vote for the leader selected, which we use as a robustness check. 
Each of the profiles were constructed by randomizing the attribute levels of seven attributes included in our conjoint, as shown in table 1. These attributes and attribute levels consist of theoretically informed discrete values that are likely to affect evaluations of prospective prime ministers. Each respondent was asked to make six such evaluations.

\section{Table 1. Conjoint attributes and attribute levels}

\begin{tabular}{|c|c|c|}
\hline Role & Attribute & Levels ( $\mathrm{R}=$ Reference category) \\
\hline \multirow[t]{3}{*}{ Democratic norm } & Violence against opposition & 1. Condemns physical attacks against opposition candidates (R) \\
\hline & & 2. Does not condemn physical attacks on opposition candidates \\
\hline & & 3. Incites physical attacks against opposition candidates. \\
\hline \multirow[t]{2}{*}{ Democratic norm } & Decisions of judicial officials & $\begin{array}{l}\text { 1. Must be respected even if they may have a negative effect on } \\
\text { policies advanced by his/her party }(\mathrm{R})\end{array}$ \\
\hline & & $\begin{array}{l}\text { 2. Do not have to be respected if they may have a negative effect on } \\
\text { policies advanced by his/her party }\end{array}$ \\
\hline \multirow{3}{*}{$\begin{array}{l}\text { Ideological } \\
\text { congruence }\end{array}$} & Ideology & 1. Leftist (R) \\
\hline & & 2. Centrist \\
\hline & & 3. Rightist \\
\hline \multirow[t]{3}{*}{ Policy congruence } & Position on immigration policy & 1. Reduce number of immigrants $(\mathrm{R})$ \\
\hline & & 2. Maintain number of immigrants at current level \\
\hline & & 3. Increase number of immigrants \\
\hline \multirow[t]{2}{*}{ Background } & Gender & 1. Female (R) \\
\hline & & 2. Male \\
\hline \multirow[t]{3}{*}{ Background } & Education & 1. Low (R) \\
\hline & & 2. Intermediate, \\
\hline & & 3. High \\
\hline \multirow[t]{3}{*}{ Populism } & Decisions will reflect & 1. Demands of ordinary citizens (R) \\
\hline & & 2. Compromises between political elites \\
\hline & & 3. Compromises between relevant social groups \\
\hline
\end{tabular}

We include two forms of democratic transgressions. The first concerns violence against opposition politicians, since it is a basic democratic norm that political violence has no place in democratic societies. Here the first level involves a clear condemnation of violence against opposition candidates; the second level describes the absence of such condemnations, while the third involves the profile inciting violence against opposition candidates to grasp the extent of the commitment to democratic norms.

The other democratic transgression concerns the rule of law and the basic democratic principle that politicians should respect the insulation of judicial officials from political pressure (Levitsky and Ziblatt 2018, Mettler and Lieberman 2020). This attribute includes two levels; one where the profile clearly states that decisions from judicial officials must be respected even 
when they may have a negative effect on policies advanced by his/her party, while the other level is the abstention of such promises in the case where the decision could have adverse effects for policies advanced by the party that the politicians represents.

These attributes include clear transgression of key democratic norms. For the inferences from conjoint experiments to be valid, the treatments should be realistic to the respondents (Mares and Young 2019). Even though our examples are rather extreme, violence against politicians has become increasingly common in established European democracies and in Finland. In the run up to the 2019 parliamentary elections in Finland, electoral candidates were physically attacked during campaign events even though political violence had until then been rare (Wass et al. 2020). However, based on the considerations above, it remains unclear how the general population reacts when confronted with such democratic transgressions.

To gauge the importance of policy congruence, we include a policy position that has been prominent in recent years, namely policy position on immigration (Norris and Inglehart 2019: 175-206). Here there are also three levels, as the leaders can promise to decrease number of immigrants, maintain the status quo, or increase the number of immigrants. We also include ideological placement on a left/right scale (leftist, centrist, rightist) to gauge the importance of ideological congruence. To examine the importance of congruence, these two attributes are aligned with respondents' answers to similar questions, as described below.

While these attributes are central for the current purposes, we include other attributes to present a complete leader profile to make the assessments more realistic for the respondents.

We also include basic background characteristics that are common to include in conjoint experiments of candidate evaluations (Kirkland and Coppock 2018, Breitenstein 2019, Christensen et al. 2020): gender (male vs female), education (low, intermediate, high educational attainment). While these attributes are important for creating realistic profiles, the 
substantial impact is of less interest in this case, and we do not here offer specific hypotheses for their effects on favorability.

Finally, we include an attribute gauging the extent of populism of the prospective leaders since this has been a major component in explaining the lure of anti-democratic politicians. ${ }^{\text {iii }}$ Based on the definition of Mudde (2004: 543), we divide this attribute into three levels, where the profile promises that decisions will reflect either the demands of ordinary people, compromises between political elites or compromises between different interests in society. While this simple

distinction does not capture all possible connotations of populism, it adds extra conceptual validity that the two latter levels include a 'compromise', since this is frequently seen as contrary to populism (Mudde 2004: 544, Rostbøll 2020).

Some combinations of attribute levels may be impossible or highly implausible, which can make it necessary to exclude certain combinations from occurring (Hainmueller et al. 2014). While some of the combinations here may seem unlikely to occur in contemporary politics (e.g., a leader being both leftist and in favor of restricting immigration), none of them are logically impossible and therefore no restrictions were added to the randomization, as is also recommended by Hainmueller et al. (2014).

\section{Data, variables, and methods}

\subsection{Presentation of survey}

The data for testing our hypotheses come from a conjoint experiment embedded in a survey distributed to a representative sample of the Finnish population when it comes to age, gender, and region of living, as shown in the appendix $(n=1030) .{ }^{\text {iv }}$ Since the sample matches the general population well, we do not employ weighting when analyzing the results. The design with 1030 respondents performing six tasks and a maximum of three attribute levels entails that for H1a and $\mathrm{H} 1 \mathrm{~b}$, we can estimate relatively small effects sizes of $\mathrm{AMCE}=0.03$, or changes in 
favorability of 3 percentage points, with an estimated statistical power of $81 \%$, and effects sizes of AMCE $=0.04$ with a statistical power of $95 \%$, as shown in the appendix (Lukac and Stefanelli 2020). Hence, the study is well-powered to correctly detect causal effects of a magnitude where the effects have concrete implications. We were unable to perform similar power analysis for our sub-group analyses since group sizes were unknown beforehand, which means some groups have a relatively low number of respondents. There is therefore still a need to examine whether these results can be replicated in studies with more powerful research designs. The data was collected between 27 May to 1 June 2020 via an online panel recruited through Qualtrics. In the survey, the respondents first completed basic socio-demographic information, before being asked a series of questions about their general political attitudes and preferences. Following this, the respondents completed the conjoint experiment.

Finland constitutes a fitting case for examining how transgressions of democratic norms affect evaluations of political leaders for two reasons. First, Finland is a multiparty parliamentary democracy where large coalitions and consensual politics are deeply ingrained political norms (Karvonen 2014) and is thereby provides an example of 'consensual' political system (Lijphart 2012). This consensus system is likely to affect how citizens perceive violations of established democratic norms. Ideological polarization has been rather low in Finland in comparative context (Isotalo et al. 2020, Reiljan 2020, Fornaro 2021). Even though affective polarization has increased in Finland recently, it "still remains on a moderate level when looked at from an international perspective" (Kekkonen and Ylä-Anttila 2021, 5, see also Reiljan 2020 and Wagner 2021).This makes for an important contrast to the previous literature that has studied citizens' propensity to support democratic norms mostly in highly polarized contexts such as the US and Venezuela and has argued that individual-level political polarization drives citizens' willingness to overlook democratic violations (Svolik 2019, 2020, Graham and Svolik 2020, on polarization see also Levitsky and Ziblatt 2018, Mettler and Lieberman 2020). Second, if we 
expect voters to defend democratic principles and judicial independence, this should be especially salient in a context where trust in democracy and democratic institutions is high. Finnish voters report one of the highest levels of democratic satisfaction in Europe, and the level of satisfaction has remained rather stable over time (Bäck et al. 2016; Karvonen 2014, Kestilä-Kekkonen 2015, Rapeli and Koskimaa 2020). The level of political trust among the Finnish voters is also particularly high in the European context (Kestilä-Kekkonen 2015, Söderlund 2019). Both aspects entail that we consider Finland to be a 'least-likely case' for tolerance for violations of democratic norms.

\subsection{Variables}

The dependent variable is whether a given profile was chosen or not in a comparison. All attribute levels are coded as dummy variables indicating whether the attribute in question was shown or not. The randomization of the attribute levels across respondents entail that it is unnecessary to include control variables to ascertain the causal effects (Hainmueller et al. 2014). However, it is often valuable to examine differences in effect sizes across sub-groups since there may be important differences in effects for certain groups (Abramson et al. 2019, Hainmueller et al., 2014, Leeper et al. 2020). Since these variables are observed rather than randomized, we can only observe whether differences in effects exist depending on the characteristics, not ascertain that the moderator variables cause the observed differences in effects (Kam and Trussler, 2017: 793).

In line with our hypotheses, we examine differences in effects across two types of congruence: Ideological congruence and immigration policy congruence, and three types of political disaffection: Political trust, satisfaction with democracy and external political efficacy. ${ }^{\mathrm{v}}$

Ideological congruence is constructed based on the attribute ideology and a survey question where respondents indicated their ideological left-right placement on a scale coded $0-10$ (10 
furthest to the right). The variable ideological congruence has four categories: 1) Mismatch (respondent and profile had different ideological positions ${ }^{\mathrm{vi}}, 66.7 \%$ ); 2) Both leftist (Profile was leftist and respondent indicated 0-4 on the scale, 11.0\%); 3) Both centrist (profile was centrist and respondent chose 5 on the scale, 10.4\%); and 4) Both rightist (Profile was rightist and respondent chose 6-10 on the scale, $11.9 \%$ ).

The immigration policy congruence variable is constructed based on the attribute immigration policy and an index ranging from 0-8 based on two questions where respondents indicated their attitudes to immigrant workers and asylum seekers on five-point Likert scales (higher scores indicates more positive attitudes to immigration). The immigration congruence variable also has four categories: 1) Mismatch (respondent and profile had different attitudes to immigration, $66.7 \%$ ); 2) Both pro-immigration (profile promised to increase number of immigrants and respondent scored 5-8 on the index, 12.4\%); 3) Both intermediate (profile promised to maintain the status quo and respondent scored 4 on the index, 8.9\%); and 4) Both anti-immigration (Profile promised to lower the number of immigrants and respondent scored 0-3 on the index, $12.1 \%)$

Political trust is measured with an index based on respondents' trust in parliament, politicians, political parties, and government (each item scored 0-10, index 0-40, Cronbach's alpha= 0.94). The respondents were classified into three categories based on their scores: Disaffected (0-14, $19.6 \%)$, Intermediate $(15-25,38.4 \%)$, Satisfied (26-40, 42.0\%). Satisfaction with democracy is measured with a single item where respondents indicate their level of satisfaction with the way democracy works in Finland on a scale 0-10. Respondents who indicate 0-4 are classified as Disaffected (18.4\%), those who pick 5 are classified as intermediate $(10.8 \%)$, while those scoring 6-10 are classified as Satisfied (70.9\%). For external efficacy, we form an index based on answers to three questions scored on a five-point Likert scale (1. Elected representatives quickly forget the worries of ordinary citizens, 2. Citizens' opinions are considered in political 
decision-making, 3. Politicians do not care about the opinions of ordinary people, Cronbach's alpha=0.75). The index ranging $0-12$ was constructed so that higher scores indicate a higher level of external efficacy. Here respondents scoring 0-3 were classified as Disaffected (37.4\%), 4-6 as Intermediate (44.4\%) and those scoring 7-12 were regarded as Satisfied (18.3\%).

\subsection{Methods of analysis}

All analyses are linear regression analyses with standard errors clustered at the respondent level to consider that each of the 1030 respondents provides six evaluations of two profiles (Hainmueller et al. 2014). Due to the randomization of attributes, the coefficients can be interpreted as Average Marginal Component Effect (AMCE), which describes how much the probability of choosing a leader profile would change on average if one of the leader's attributes were switched from the reference category to the particular attribute level (Hainmueller et al. 2014).

These are population averages, but there may be important differences in effects across subgroups (Leeper et al. 2020). As outlined above, we are interested in differences across ideological congruence, policy congruence, and political disaffection. To determine whether there are differences in effects, interaction terms between the attributes and the relevant groups are included (Hainmueller et al. 2014). This conditional AMCE shows effect sizes for the different groups. To assess the implications of the interaction effects, we rely on formal tests of significance and assess practical implications by seeing whether the effects have similar magnitudes and directions for different values of the moderator (Kam and Franzese, 2007).

A final measure of interest is the marginal mean, which describes the level of favorability toward leaders with a particular feature level when ignoring all other features (Leeper et al. 2020). While the AMCE depend on the reference category used, the marginal mean allows us to verify the popularity of a given attribute level in descriptive terms without using a reference 
category, which may be somewhat arbitrary and can lead to misleading interpretations when assessing differences across subgroups (Leeper et al. 2020).

As recommended by Hainmueller et al (2014), we report the results in coefficient plots. The estimates are indicated by dots with lines indicating the $95 \%$ confidence intervals to show the uncertainty surrounding this estimate. For the AMCEs, there is a vertical line at 0 , and when the confidence intervals cross this line, it entails that the effect is not statistically significant at $\mathrm{p}<0.05$. For the marginal means, the line is at 0.5 since this indicates the point where less than half of the respondents prefer this option when presented with it. The full regression results are included in the appendix.

\section{Analysis}

As a prelude to the conjoint analysis, we in Figure 1 present descriptive evidence to respondents' opinions on basic democratic norms. This is based on the extent of agreement with some statements on basic democratic norms. 


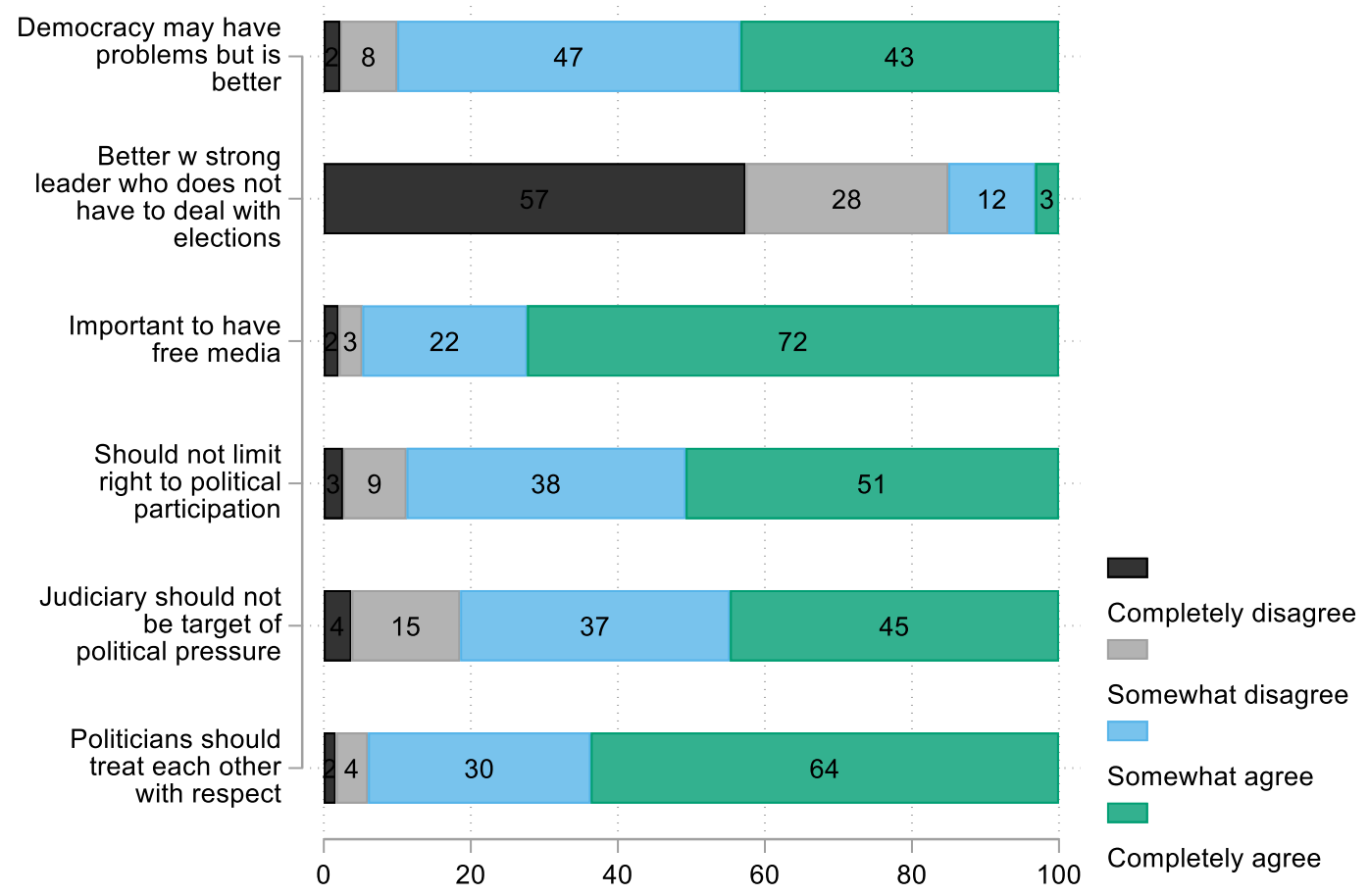

An overwhelming majority of Finns express support for basic democratic norms when asked directly. It is at most $19 \%$ who do not agree that the judiciary should not be the target of political pressure, 94\% agree that politicians should treat each other with respect. If we combine all questions to an index with higher scores indicating higher support for democratic principles and norms ranging from $0-18$, the mean is 14.5 and only $5 \%$ of respondents score 9 or less on the index. This clearly demonstrates that Finns support democratic norms when they are asked directly. The question is whether this support is also evident when asking them for implicit preferences in a conjoint experiment.

The results for the first pair of hypotheses are shown in Figure 2. 

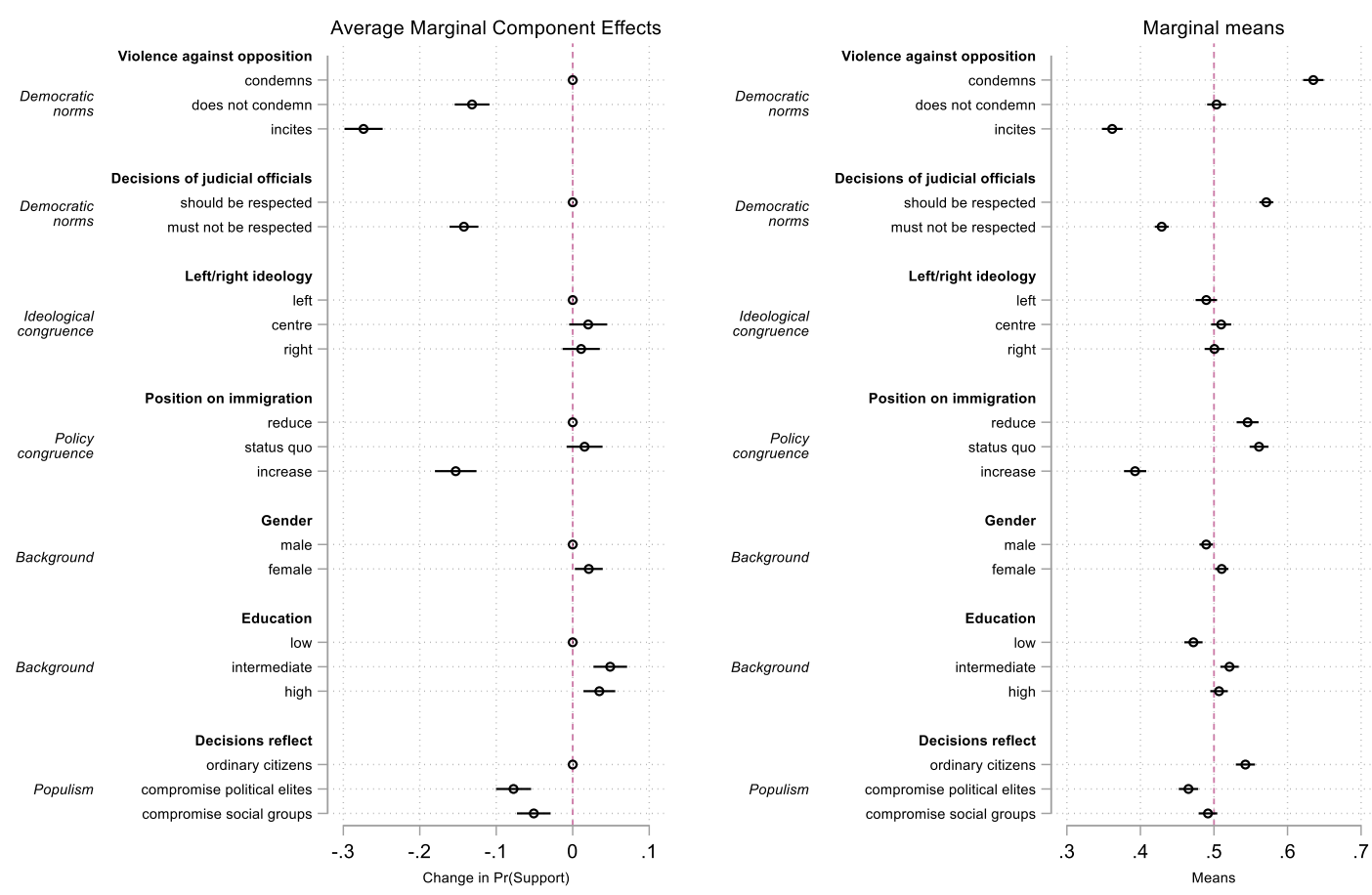

The results as expected show that violating democratic norms have negative effects on favorability. For violence against opposition politicians, a leader who does not condemn the use of violence is 13 percentage points worse of $(\mathrm{AMCE}=-0.13, \mathrm{p}=0.000)$ while a leader who incites violence loses 27 percentage points $(\mathrm{AMCE}=-0.27, \mathrm{p}=0.000$ ), comparing each to a leader who condemns the use of violence. However, the marginal means reveal that while a leader who incites violence is picked about $36 \%$ of the time, a leader who does not condemn violence is picked about $50 \%$ of time, showing that the consequences of such less explicit democratic transgression are less severe. Even if people prefer a leader who clearly condemns violence, many are willing to ignore not condemning physical attacks when selecting a leader. When prospective leaders indicate that court decisions do not have to be respected under all circumstances, they drop 14 percentage points compared to leaders who respect court decisions $(\mathrm{AMCE}=-0.14, \mathrm{p}=0.000)$. The marginal means entail that a leader who respects court decisions is picked $57 \%$ of the time regardless of other attributes while a leader who makes no such 
promise is selected $43 \%$ of the time. These effect sizes are large, entailing that, on average, Finns strongly punish politicians for explicit democratic violations.

However, we have hypothesized that ideological and policy congruence may moderate reactions to democratic violations by politicians. We therefore move on to exploring $\mathrm{H} 2 \mathrm{a}$ and b concerning differences across policy position congruence and $\mathrm{H} 3 \mathrm{a}$ and $\mathrm{b}$ on ideological congruence on the left-right dimension in Figure 3.

Figure 3. Differences in effects of norm transgressions depending on policy congruence and ideological congruence (conditional AMCEs and marginal means)

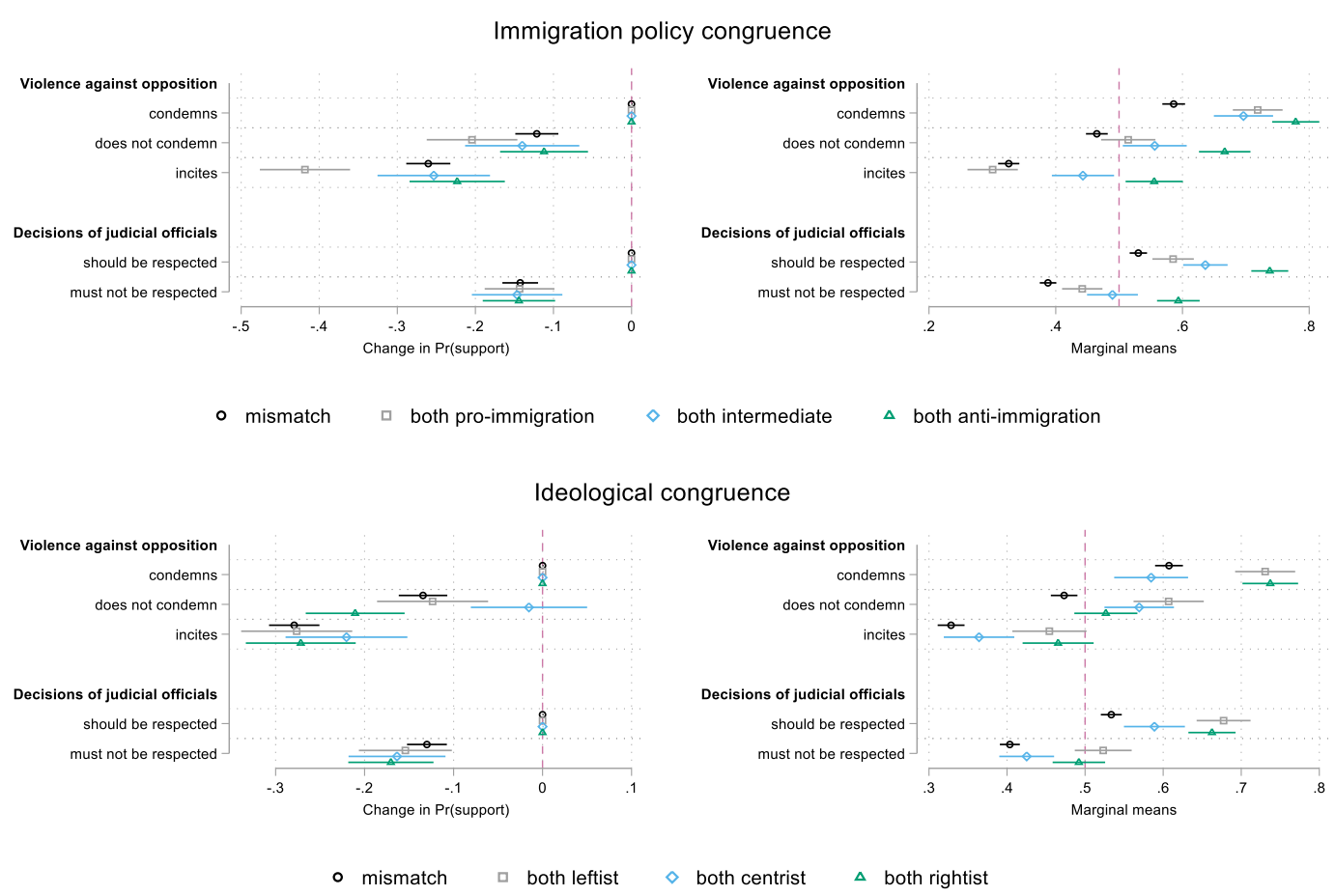

The two upper panes show conditional AMCEs and marginal means for policy congruence. There are no significant interaction terms for respecting judicial independence. For violence against opposition, the negative impact is stronger for pro-immigration congruence and both not condemning violence $(\mathrm{B}=-0.08, \mathrm{p}=0.009)$ and inciting violence $(\mathrm{B}=-0.16, \mathrm{p}=0.000)$. The marginal means show that policy congruence entails that respondents will often pick leaders even when they transgress basic democratic norms. This is clearest when both leader and 
respondent are anti-immigration, where leaders who incite violence against opposition politicians are picked $56 \%$ of the time they are shown, while the corresponding figure for not respecting judicial officials is $59 \%$ and for not condemning violence it is $67 \%$. Hence people are willing to ignore even major democratic transgressions when there is agreement on reducing the number of immigrants. Intermediate and pro-immigration policy congruence also means that people are willing to ignore some transgressions. When there is pro-immigration congruence, people pick leaders who fail to condemn violence $51 \%$ of the time and status quo congruence entails that people select such leaders $56 \%$ of the time. However, these groups are less willing to selected leaders inciting violence, indicating that policy congruence does not override this type of transgression. This shows that it is important to be aware of the different types of transgression and their severity.

A similar pattern can be observed in the two lower panes, which show the corresponding results for ideological congruence. There are no significant interaction terms for respecting the decisions of judicial officials, but for violence against the opposition, there are significant interaction terms for profiles not condemning attacks and centrist congruence $(B=0.12$, $\mathrm{p}=0.001)$ and rightist congruence $(\mathrm{B}=-0.08, \mathrm{p}=0.015)$. While the differences for the conditional AMCEs appear small, the marginal means show that people are more likely to pick leaders even when they commit democratic transgressions when there is ideological congruence. People generally prefer leaders who condemn violence, but when there is ideological congruence, people select leaders who do not condemn violence more than $50 \%$ of the times such a profile is shown. For leftist congruence, it is even $61 \%$ of the time that such a profile is selected. Leaders who do not promise to respect judicial officials are also selected about $52 \%$ of the time when there is leftist ideological congruence and $49 \%$ of the time when there is rightist ideological congruence with the leader profile. Hence, while people prefer leaders who abide 
by democratic norms, ideological congruence appears to be more important than democratic principles when they evaluate potential political leaders.

We now turn to $\mathrm{H} 4 \mathrm{a}$ and $\mathrm{b}$ and differences in effects across political disaffection. Figure 4 shows the results.

Figure 4. Differences in effects of norm transgressions across political disaffection (conditional AMCEs and marginal means)
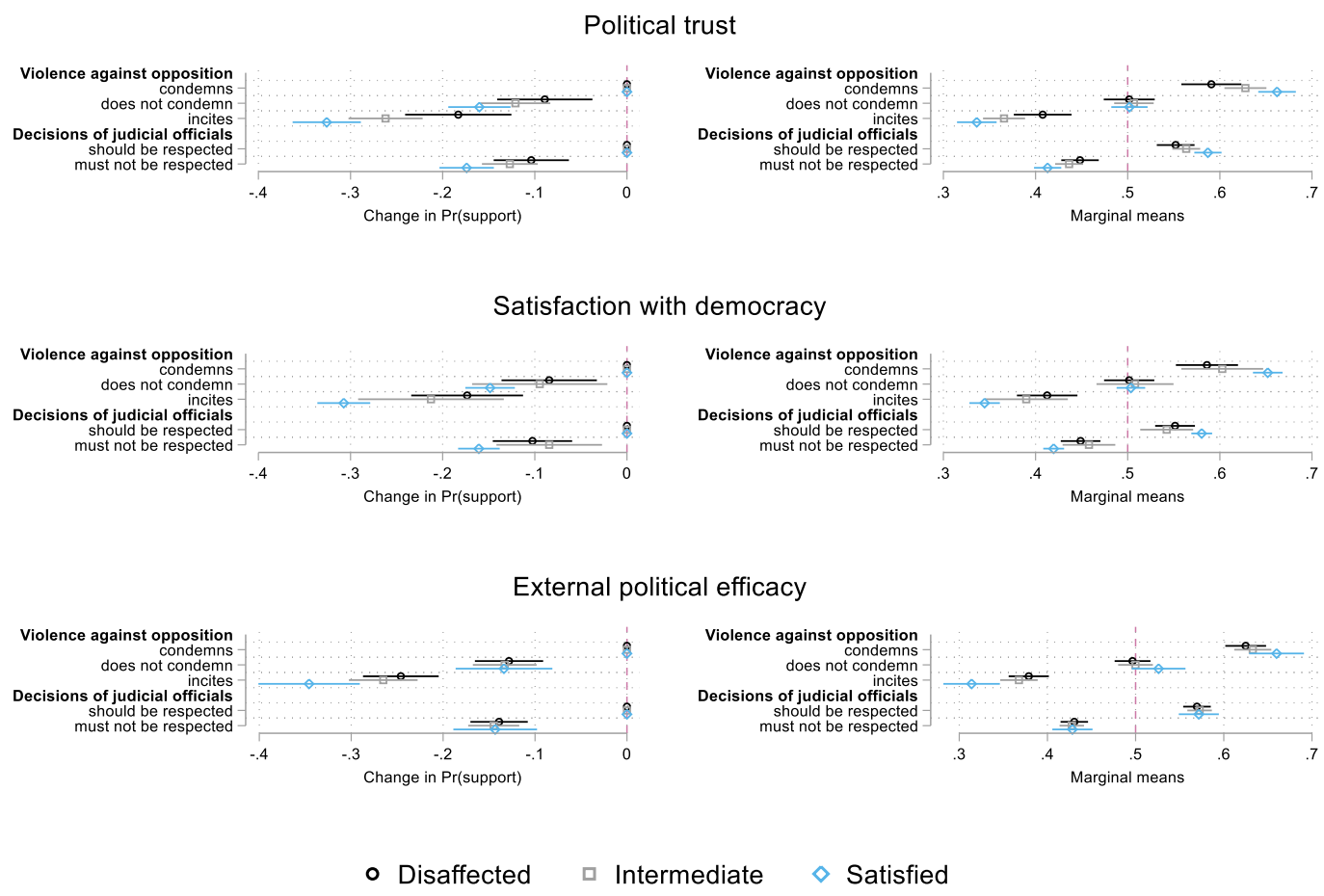

The results for political trust and satisfaction with democracy are generally in line with the expectations. For violence against opposition politicians, there are significant interaction terms for satisfaction when it comes to political trust and both not condemning $(\mathrm{B}=-0.07, \mathrm{P}=0.024)$ and inciting violence $(\mathrm{B}=-0.14, \mathrm{p}=0.000)$. The same is true for satisfaction with democracy, where the effects differ for not condemning violence $(B=-0.06, p=0.030)$ and inciting violence $(\mathrm{B}=-0.13, \mathrm{p}=0.000)$. For disrespecting judicial officials, we find significant interaction terms for the satisfied when it comes to political trust $(B=-0.07, p=0.006)$ and satisfaction with democracy $(B=-0.06, p=0.018)$. These differences in effects entail that satisfied citizens (i.e., 
those with high trust and/or satisfaction with democracy) are more likely to condemn democratic transgressions. These effects are more muted, albeit still negative, among those who are dissaffected.

The situation is slightly different for external political efficacy where there are no significant interaction terms. While there is thus no clear-cut evidence for differences depending on the level of efficacy, the pattern largely resembles the one found for the other items, since the satisfied are less likely to pick leader who commit democratic transgressions.

\subsection{Robustness checks}

We performed various robustness checks to ascertain the robustness of these results. The results are shown in the online appendix, and we only outline the most relevant findings here.

First, the choice-based conjoint format used here means that respondents may be forced to select a leader profile that they do not really like. We therefore also asked a follow-up question after each round, where we asked respondents whether they would also vote for the leader they had just selected. This is a more demanding test of the impact of democratic transgressions since respondents get two chances to rebuff unjustifiable elite behavior. We reran the analyses for the follow-up question only for the candidates picked in the choice-based conjoint, meaning the number of units of analysis is halved from 12360 to 6180. The results are shown in Figures A2A4 in the online appendix. As might be expected, the effects are generally weaker when concerned with voting since some indicate they would not vote for the selected profile. Nevertheless, the marginal means show that almost $30 \%$ of the respondents would also vote for a selected leader profile who violates central democratic principles, which may still be a cause for concern.

The patterns are generally similar for voting propensity when examining the corresponding results for ideological and policy congruence. Anti-immigration and right-wing congruence in 
particular entail that people are willing to overlook democratic transgressions and vote for a leader regardless. A leader who does not condemn violence is picked more than $40 \%$ when there is policy congruence, and slightly less than $40 \%$ of the time when he/she incites violence. While we should not interpret such percentages as vote shares (Abramson et al. 2019), it nonetheless indicates that many are willing to ignore democratic incivilities to achieve their desired policy goals. The results for political disaffection are also similar since those with high satisfaction are generally much less likely to accept democratic transgressions, although the differences are not as pronounced as in the forced choice conjoint.

Overall, we take these results to mean that the findings are not solely an artefact of the forced choice conjoint design.

Another important aspect is to examine whether effects are similar across rounds and independent of placement of the profile (left-right), since it could affect the findings when there are systematic differences (Hainmueller et al. 2014). The results reported in Figure A5 show that there is no uniform trend for differences, meaning we are confident such differences do not bias the results.

\section{Concluding discussion}

Our results contribute to the emerging line of scholarship on citizens reactions to democratic violations by politicians (Carey et al. 2020, Svolik 2020, Graham and Svolik 2020), as well as the earlier literature on the link between democratic disaffection and democratic system support (see, e.g., Norris 1999, 2011).

First, we examined the support of Finnish citizens of several key aspects of democracy when these were measured by answers to standard direct survey questions. We found that an overwhelming majority supported core democratic principles when asked directly. However, the results were much more nuanced when the support for democratic principles was measured 
indirectly via a conjoint experiment. The results for our conjoint experiment generally support the notion that clear democratic transgressions are punished by the public. However, the results also reveal that less explicit violations, where leaders fail to condemn violence against opposition politicians, can go unpunished by people as these are still picked about $50 \%$ of the time. These results support the contention that direct survey questions may not capture the extent of 'true' democratic support in established democracies (Svolik 2020, Graham and Svolik 2020). While people generally agree with basic democratic norms when asked directly, many will fail to act in accordance with these beliefs when put in a position where it is necessary to make a trade-off between democratic ideals and specific policy goals. This 'trade-off' mechanism, which has also been found in previous literature (see, e.g., Breitenstein 2019, Graham and Svolik 2020), suggests that people are willing to support undemocratic or corrupt politicians when these politicians are co-partisans or deliver other benefits to the voters.

In line with this notion, we find that people are more willing to ignore even serious and explicit violations when they agree with a potential leader either ideologically or on the policy issue of immigration. While people generally prefer leaders who do not transgress democratic norms, many are willing to overlook not condemning violence or disrespecting judicial officials when there is ideological congruence or a respondent and the potential leader both agree that immigration should be restricted. Our results show that the respondents who are opposed to immigration are willing to overlook even blatantly authoritarian behavior by a prospective political leader, that is, inciting violence against the opposition, when this leader is also in favor of curtailing immigration. The issue of immigration appears to be such an important policy issue (a kind of 'lexicographic preference') for some citizens that it overrides all other political dimensions. These results thereby may help explain the apparent success of political leaders who violate basic democratic norms in several established democracies. 
We have here extended previous findings to Finland, a stable democracy with a consensual political culture, which may be considered a least likely case for this sort of mechanism to operate. However, even here we find that some people are willing to ignore serious violations of basic democratic norms when leaders represent policies or ideological positions that these people concur with. This does not bode well for democracy in less stable political regimes plagued by intense social conflicts. Under such circumstances, large parts of the electorate may become open for ignoring, or even openly supporting, violations of democratic principles if leaders otherwise appear able to deliver political outcomes that correspond to popular demand (see McCoy and Somer 2019, Svolik 2019 and 2020).

Finally, we examine the extent to which political disaffection moderates the impact of democratic transgressions. The results here show that the effects of democratic transgressions are more severe when people have high political trust and/or satisfaction with democracy, while the disaffected do not as strongly condemn transgressions. While low trust and/or satisfaction with democracy does not necessarily entail low commitment to democracy per se, these results show that citizens who are satisfied with democratic performance will act as guardians of democracy, whereas the disaffected are more likely to be passive bystanders. It would seem there is little protection to be had from the critical citizens some suggest should be more eager to protest basic democratic norms (Inglehart 1997, Norris 1999). This thereby indicates that even if disaffection does not necessarily constitute a direct threat to democracy, it can erode the mechanisms that ensure that leaders respect basic democratic norms.

These findings come with some caveats. While conjoint experiments are well suited for examining multidimensional political choices, they are limited in the number of attributes that can be included in the experimental setting. We were only able to examine the policy issue of migration, which may be said to occupy a particular role in contemporary political discourse in most democracies. There is therefore a need to examine in greater detail whether other policy 
areas can play a similar role, and if so, under what circumstances. There is also a need to examine further what citizen characteristics explain the propensity to forgive transgressions of democratic norms. Here a focus on diffuse support for democracy (Easton 1965) versus preferences for more authoritarian regimes may constitute a promising avenue of future research. Furthermore, while both ideological and affective polarization have been low in Finland by comparative standards (Isotalo et al. 2020, Rejlman 2020, Wagner 2021), recent studies have shown that affective polarization has been increasing in Finland, although it is still at a comparatively moderate level (Kekkonen and Ylä-Anttila 2021). Further research is therefore needed to probe the potential links between affective polarization and the support for democracy in established democracies.

Despite these limitations, our results contribute to the growing number of studies examining the mechanisms of democratic backsliding in contemporary democracies. 


\section{Endnotes}

${ }^{\mathrm{i}}$ The phrasing of these hypotheses was altered slightly from the preregistration since we in the preregistration used the term "candidate" rather than "leader", but the intention is identical.

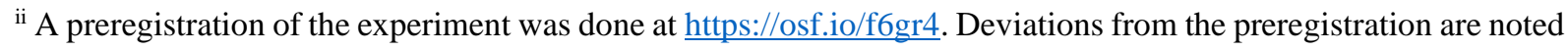
in the text and are compiled in the online appendix. Data and Stata Do-file for the replication of all analyses can be accessed at https://osf.io/3f49x/.

iii This aspect is to be examined in more detail in a separate paper.

iv This type of study does not require ethical approval according to the guidelines of Finnish National Board on Research Integrity when participants give informed consent, and the study does not violate physical integrity, does not involve minors, does not expose participants to exceptionally strong stimuli, and does not cause harm or a safety risk for participants or their families (https://tenk.fi/en/ethical-review/ethical-review-human-sciences).

${ }^{\mathrm{v}}$ In the preregistration, we also present hypotheses for differences across generations, but this will now be examined in a separate paper.

${ }^{\mathrm{vi}}$ Since our interest here is to examine the impact of congruence rather than mismatch, we do not distinguish between different types of mismatch (i.e. leftist respondent and rightist profile). This is also the case for the policy congruence variable. 


\section{References}

Abramson, Scott F, Korhan Koçak, and Asya Magazinnik. 2019. 'What Do We Learn About Voter Preferences from Conjoint Experiments?'. Unpublished working paper. Accessed from: https://pdfs.semanticscholar.org/023a/24a7dfaddfce626d011596b187f26361ee86.pdf.

Alexander, Amy and Christian Welzel. 2017. "The Myth of Deconsolidation: Rising Liberalism and the Populist Reaction", Journal of Democracy Online Exchange on "Democratic Deconsolidation", Accessed from: https://www.journalofdemocracy.org/wpcontent/uploads/2018/12/Journal-of-Democracy-Web-Exchange-Alexander-and-Welzel.pdf.

Almond, Gabriel and Sidney Verba. 1963. The Civic Culture: Political Attitudes and Democracy in Five Nations. Princeton University Press.

Azari, Julia R. and Jennifer K. Smith. 2012. "Unwritten Rules: Informal Institutions in Established Democracies". Perspectives on Politics. 10(1): 37-55. DOI: https://doi.org/10.1017/S1537592711004890

Bäck, Maria Kestilä-Kekkonen, Elina and Peter Söderlund (2016): Suomalaisten poliittinen luottamus ja siihen vaikuttavat tekijät, in Poliittisen osallistumisen eriytyminen Eduskuntavaalit 2015. Grönlund, K. \& Wass, H. (eds.). Helsinki: Oikeusministeriö, 379-397

Bermeo, Nancy. 2016. “On Democratic Backsliding.” Journal of Democracy. 27(1): 5-19. DOI: https://doi.org/10.1353/jod.2016.0012

Borg, Sami, Elina Kestilä-Kekkonen and Hanna Wass. 2020. Politiikan ilmastonmuutos. Eduskuntavaalitutkimus 2019. Oikeusministeriön julkaisuja, Selvityksiä ja ohjeita, 2020:5.

Breitenstein, Sofia. 2019. 'Choosing the Crook: A Conjoint Experiment on Voting for Corrupt Politicians'. Research \& Politics 6(1): 1-8. https://doi.org/10.1177\%2F2053168019832230

Carey, John, Katherine Clayton, Gretchen Helmke, Brendan Nyhan, Mitchell Sanders \& Susan Stokes. 2020. "Who will defend democracy? Evaluating tradeoffs in candidate support among partisan donors and voters", Journal of Elections, Public Opinion and Parties, DOI: https://doi.org/10.1080/17457289.2020.1790577

Christensen, Henrik Serup, Marco S La Rosa, and Kimmo Grönlund. 2020. 'How Candidate Characteristics Affect Favorability in European Parliament Elections: Evidence from a Conjoint Experiment in Finland'. European Union Politics 21(3): 519-40. DOI: https://doi.org/10.1177/1465116520929765

Christensen, Henrik Serup. 2020. 'How Citizens Evaluate Participatory Processes: A Conjoint Analysis'. European Political Science Review 12(2): 239-53. doi: https://doi.org/10.1017/S1755773920000107

Chiopris, Caterina, Monica Nalepa and Georg Vanberg. 2021. A Wolf in Sheep's Clothing: Citizen Uncertainty and Democratic Backsliding. Working paper. Accessed at: https://www.monikanalepa.com/uploads/6/6/3/1/66318923/chioprisnalepavanberg.pdf

Claassen, Christopher. 2020. “Does Public Support Help Democracy Survive?”, American Journal of Political Science, 64 (1): 118-134. DOI: https://doi.org/10.1111/ajps.12452

Dahl, Robert A. 1956. A Preface to Democratic Theory. Chicago: University of Chicago Press.

Dahl, Robert A. 1991. Democracy and Its Critics. New Haven: Yale University Press. 
Easton, David. 1965. A Systems Analysis of Political Life. John Wiley \& Sons, Inc.

Fearon, James. 2011. "Self-enforcing Democracy." Quarterly Journal of Economics 126: 16611708. DOI: https://doi.org/10.1093/qje/qjir038

Foa, Roberto Stefan, and Yascha Mounk. 2016. 'The Danger of Deconsolidation: The Democratic Disconnect'. Journal of Democracy 27(3): 5-17. DOI: https://doi.org/10.1353/jod.2016.0049

Foa, Roberto Stefan, and Yascha Mounk. 2017. 'The Signs of Deconsolidation'. Journal of Democracy 28(1): 5-16. DOI: https://doi.org/10.1353/jod.2017.0000

Fornaro, Paolo. 2021. “Onko suomalainen politiikka polarisoitunut?”, Kansalaisuuden kuilut ja kuplat, 1/2021. Available at: https://bibu.fi/wp/wpcontent/uploads/2021/01/BIBUpolarisaatioBrief.pdf

Franchino, Fabio, and Francesco Zucchini. 2015. 'Voting in a Multi-Dimensional Space: A Conjoint Analysis Employing Valence and Ideology Attributes of Candidates'. Political Science Research and Methods 3(2): 221-41. doi: https://doi.org/10.1017/psrm.2014.24

Graham, Matthew H. and Milan W. Svolik, 2020. "Democracy in America? Partisanship, Polarization, and the Robustness of Support for Democracy in the United States", American Political Science Review, 114(2), 392-409, doi: https://doi.org/10.1017/S0003055420000052

Hainmueller, Jens, Dominik Hangartner, and Teppei Yamamoto. 2015. 'Validating Vignette and Conjoint Survey Experiments against Real-World Behavior'. Proceedings of the National Academy of Sciences 112(8): 2395-2400. https://doi.org/10.1073/pnas.1416587112

Hainmueller, Jens, Daniel J. Hopkins, and Teppei Yamamoto. 2014. 'Causal Inference in Conjoint Analysis: Understanding Multidimensional Choices via Stated Preference Experiments'. Political Analysis 22(01): 1-30. https://doi.org/10.1093/pan/mpt024

Helmke, Gretchen and Steven Levitsky, 2004. 'Informal Institutions and Comparative Politics: A Research Agenda', Perspectives on Politics, 2 (4): 725-740. DOI: https://doi.org/10.1017/S1537592704040472

Helmke, Gretchen, and Frances Rosenbluth. 2009. 'Regimes and the Rule of Law: Judicial Independence in Comparative Perspective', Annual Review of Political Science 12 (1): 345366. DOI: https://doi.org/10.1017/S1537592704040472

Inglehart Ronald (1997) Modernization and Postmodernization: Cultural, Economic, and Political Change in 43 Societies. Princeton: Princeton University Press.

Isotalo, Veikko, Södelund, Peter and Åsa von Schoultz. 2020. 'Polarisoituuko politiikka Suomessa? Puolueiden äänestäjäkuntien arvosiirtymät 2003-2019', Politiikan ilmastonmuutos. Eduskuntavaalitutkimus 2019. Borg, Sami, Elina Kestilä-Kekkonen and Hanna Wass (eds.). Oikeusministeriön julkaisuja, Selvityksiä ja ohjeita, 2020:5.Kam, Cindy, and Robert J. Franzese. 2007. Modeling and Interpreting Interactive Hypotheses in Regression Analysis. Ann Arbor: University of Michigan Press.

Kam, Cindy, and Marc J. Trussler. 2017. 'At the Nexus of Observational and Experimental Research: Theory, Specification, and Analysis of Experiments with Heterogeneous Treatment Effects'. Political Behavior 39(4): 789-815. DOI: https://doi.org/10.1007/s11109-016-9379-z

Karvonen, Lauri. 2014. Parties, Governments and Voters in Finland: Politics Under Fundamental Societal Transformation. ECPR Press. 
Kekkonen, Arto and Tuomas Ylä-Anttila. 2021. 'Affective blocs: Understanding affective polarization in multiparty systems'. Electoral Studies 72. https://doi.org/10.1016/j.electstud.2021.102367

Kestilä-Kekkonen, Elina. 2015. 'Suomalaisten poliittinen kiinnittyminen'. In Demokratiaindikaattorit 2015. Borg, S., Kestilä-Kekkonen, E. \& J. Westinen. (eds.). Helsinki: Oikeusministeriö. 52-63.

Kirkland, Patricia A., and Alexander Coppock. 2018. 'Candidate Choice Without Party Labels': Political Behavior 40(3): 571-91. DOI: https://doi.org/10.1007/s11109-017-9414-8

Klašnja, M and J. A. Tucker. 2013. The economy, corruption, and the vote: Evidence from experiments in Sweden and Moldova. Electoral Studies 32(3): 536-543. DOI: https://doi.org/10.1016/j.electstud.2013.05.007

Krehbiel, Jay N. 2020. 'Do Voters Punish Noncompliance with High Courts? A Cross-National Analysis'. Politics. DOI: https://doi.org/10.1177/0263395720935368.

Leeper, Thomas J., Sara B. Hobolt, and James Tilley. 2020. 'Measuring Subgroup Preferences in Conjoint Experiments'. Political Analysis 28(2): 207-21. DOI: https://doi.org/10.1017/pan.2019.30

Levitsky, Steven, and Daniel Ziblatt. 2018. How Democracies Die: What History Reveals About Our Future. Penguin UK.

Lijphart, A. (2012). Patterns of democracy: government forms and performance in thirty-six countries. ( $2^{\text {nd }}$ ed.) New Haven: Yale University Press.

Linz, Juan J. (1978). The Breakdown of Democratic Regimes, Crisis, Breakdown, \& Reequilibration. Baltimore: The Johns Hopkins University Press.

Lipset, Seymour Martin. 1959. 'Some Social Requisites of Democracy: Economic Development and Political Legitimacy'. American Political Science Review 53(01): 69-105. DOI: https://doi.org/10.2307/1951731

Lukac, M. \& Stefanelli, A. (2020). Conjoint Experiments: Power Analysis Tool. Retrieved from https://mblukac.shinyapps.io/conjoints-power-shiny/

Luo, Z., and A. Przeworski. 2019. "Democracy and Its Vulnerabilities: Dynamics of Democratic Backsliding". Working paper. Available athttps://papers.ssrn.com/sol3/papers.cfm?abstract_id=3469373. (Accessed December 16, 2019).

Mares, Isabela and Lauren E. Young. 2019. Conditionality \& Coercion: Electoral clientelism in Eastern Europe, New York: Cambridge University Press.

Mayne, Quinton and Armen Hakhverdian. 2017. 'Ideological Congruence and Citizen Satisfaction: Evidence From 25 Advanced Democracies'. Comparative Political Studies, 50(6): 822-849. https://doi.org/10.1177/0010414016639708

McCoy, Jennifer, and Murat Somer. 2019. "Polarizing Polities: A Global Threat to Democracy." The Annals of the American Academy of Political and Social Science 681: 1-273.

Mettler, Suzanne and Robert C. Lieberman. 2020. Four Threats: The Recurring Crises of American Democracy. New York: St. Martin's Press. 
Mounk, Yascha. 2018. The People Vs. Democracy: Why Our Freedom Is in Danger and How to Save It. Harvard University Press.

Mudde, Cas. 2004. 'The Populist Zeitgeist'. Government and Opposition 39(4): 542-63. DOI: https://doi.org/10.1111/j.1477-7053.2004.00135.x

Mutz, Diana C. 2016. In-Your-Face Politics: The Consequences of Uncivil Media. Princeton University Press.

Norris, Pippa (ed). 1999. Critical Citizens: Global Support for Democratic Government. Oxford: Oxford University Press.

Norris, Pippa. 2011. Democratic Deficit - Critical Citizens Revisited. Cambridge: Cambridge University Press.

Norris, Pippa. 2017. "Is Western Democracy Backsliding? Diagnosing the Risks". Journal of Democracy Online Exchange on "Democratic Deconsolidation", Accessed from: https://www.journalofdemocracy.org/wp-content/uploads/2018/12/Journal-of-Democracy-

Web-Exchange-Norris_0.pdf.

Norris, Pippa, and Ronald Inglehart. 2018. Cultural Backlash Trump, Brexit, and the Rise of Authoritarian Populism. New York: Cambridge University Press.

O'Donnell, Guillermo. 2004. 'The Quality of Democracy: Why the Rule of Law Matters'. Journal of Democracy 15(4): 32-46. DOI: https://doi.org/10.1353/jod.2004.0076

Ono, Yoshikuni, and Masahiro Yamada. 2020. 'Do Voters Prefer Gender Stereotypic Candidates? Evidence from a Conjoint Survey Experiment in Japan'. Political Science Research and Methods 8(3): 477-92. DOI: https://doi.org/10.1017/psrm.2018.41

Przeworski, Adam, Susan C. Stokes and Bernard Manin. 1999. Democracy, Accountability and Representation. Cambridge: Cambridge University Press.

Rapeli, Lauri, and Vesa Koskimaa. 2020. 'Kansalaisten kiinnittyminen politiikkaan', Politiikan ilmastonmuutos. Eduskuntavaalitutkimus 2019. Borg, Sami, Elina Kestilä-Kekkonen and Hanna Wass (eds.). Oikeusministeriön julkaisuja, Selvityksiä ja ohjeita, 2020:5.

Rejljan, Andres. 2020. "Fear and loathing across party lines' (also) in Europe: Affective polarization in European party systems'. European Journal of Political Research 59: 376-396, doi: 10.1111/1475-6765.12351

Rostbøll, Christian F. 2020. 'Second-Order Political Thinking: Compromise versus Populism'. Political Studies. https://doi.org/10.1177/0032321720910171

Schumpeter, Joseph A. 1942. Capitalism, Socialism, and Democracy. Harper \& Brothers.

Singer, Matthew. 2018. 'Delegating Away Democracy: How Good Representation and Policy Successes Can Undermine Democratic Legitimacy'. Comparative Political Studies 51(13): 1754-88. https://doi.org/10.1177\%2F0010414018784054

Stoker, Gerry. 2006. Why Politics Matters: Making Democracy Work. Basingstoke: Palgrave Macmillan.

Svolik, Milan H. 2019. "Polarization versus Democracy", Journal of Democracy, 30 (3), 2032. DOI: https://doi.org/10.1353/jod.2019.0039 
Svolik, Milan W. 2020. "When Polarization Trumps Civic Virtue: Partisan Conflict and the Subversion of Democracy by Incumbents." Quarterly Journal of Political Science 15 (1): 331. DOI: http://dx.doi.org/10.1561/100.00018132

Sydnor, Emily. 2019. Disrespectful Democracy: The Psychology of Political Incivility. New York: Columbia University Press.

Söderlund, Peter. 2019. 'Poliittinen luottamus vertailevasta näkökulmasta', Bäck, Maria and Elina Kestilä-Kekkonen (eds.). Poliittinen ja sosiaalinen luottamus. Polut, trendit ja kuilut. Valtiovarainministeriön julkaisuja. 2019: 31.

Voeten, E. (2017). "Are people really turning away from democracy?", Journal of Democracy Online Exchange on "Democratic Deconsolidation", Accessed from: https://www.journalofdemocracy.org/wp-content/uploads/2018/12/Journal-of-DemocracyWeb-Exchange-Voeten_0.pdf

Waldner, David, and Ellen Lust. 2018. "Unwelcome Change: Coming to Terms with Democratic Backsliding." Annual Review of Political Science 21: 93-113. DOI: https://doi.org/10.1146/annurev-polisci-050517-114628

Wass, Hanna, Veikko Isotalo and Jarno Limnell. 2020. "Ehdokkaiden ja äänestäjien havainnot vaalihäirinnästä.” KestiläKekkonen, Elina and Åsa von Schoultz (eds.) Ehdokkaat vaalikentillä: Eduskuntavaalit 2019. Oikeusministeriön julkaisuja, Selvityksiä ja ohjeita 2020:16.

Wagner, Markus. 2021. 'Affective Polarization in Multiparty Systems.' Electoral Studies 69: https://doi.org/10.1016/j.electstud.2020.102199

Weingast, Barry. 1997. "Political Foundations of Democracy and the Rule of Law." American Political Science Review 91: 245-63. DOI: https://doi.org/10.2307/2952354

Weingast, Barry. 2005. "Self-Enforcing Constitutions: With an Application to Democratic Stability in America's First Century". Journal of Law Economics and Organization, 29(2): 278302. DOI: https://doi.org/10.1093/jleo/ewr017

Wuttke, A., K. Gavras and Harald Schoen. (2020). 'Have Europeans Grown Tired of Democracy? New Evidence from Eighteen Consolidated Democracies, 1981-2018'. British Journal of Political Science, 1-13. DOI: https://doi.org/doi:10.1017/S0007123420000149 


\section{Biographical paragraph}

Inga Saikkonen is Academy of Finland Research Fellow in the Social Science Research Institute, Åbo Akademi University. She holds a D.Phil. in Politics from the University of Oxford. Her research interests include democratization, democratic backsliding, electoral authoritarian regimes and electoral clientelism

Henrik Serup Christensen is Senior lecturer in political science at Åbo Akademi University in Åbo, Finland. His research interests include political participation and the consequences for the functioning of democracy. 


\section{Online appendix}

\section{Appendix 1: Respondent characteristics}

Table A1 shows the characteristics of the respondents compared to the general population in Finland.

Table A1. Respondent characteristics

\begin{tabular}{|c|c|c|}
\hline $\mathrm{n}=1030$ & $\begin{array}{c}\text { Sample } \\
\%\end{array}$ & $\begin{array}{c}\text { Finnish population } \\
\text { (excluding Åland islands) } \\
\%\end{array}$ \\
\hline \multicolumn{3}{|l|}{ Age } \\
\hline $18-29$ & 23.2 & 23.0 \\
\hline $30-39$ & 18.7 & 19.0 \\
\hline $40-49$ & 18.1 & 18.0 \\
\hline $50-59$ & 19.9 & 20.0 \\
\hline $60-69$ & 20.1 & 20.0 \\
\hline \multicolumn{3}{|l|}{ Gender } \\
\hline Male & 50.0 & 50.0 \\
\hline Female & 50.0 & 50.0 \\
\hline \multicolumn{3}{|l|}{ Region } \\
\hline Helsinki area & 30.0 & 30.0 \\
\hline Northern and Eastern Finland & 24.0 & 24.0 \\
\hline Southern Finland & 21.0 & 21.0 \\
\hline Western Finland & 25.1 & 25.0 \\
\hline
\end{tabular}

Since there were no major differences between the sample and the general population, no weighting was applied during the analyses. 
8 Appendix 2: Power analysis

Figure A1. Power analysis (Achieved power when varying assumed effect size from 0.03 to 0.04)
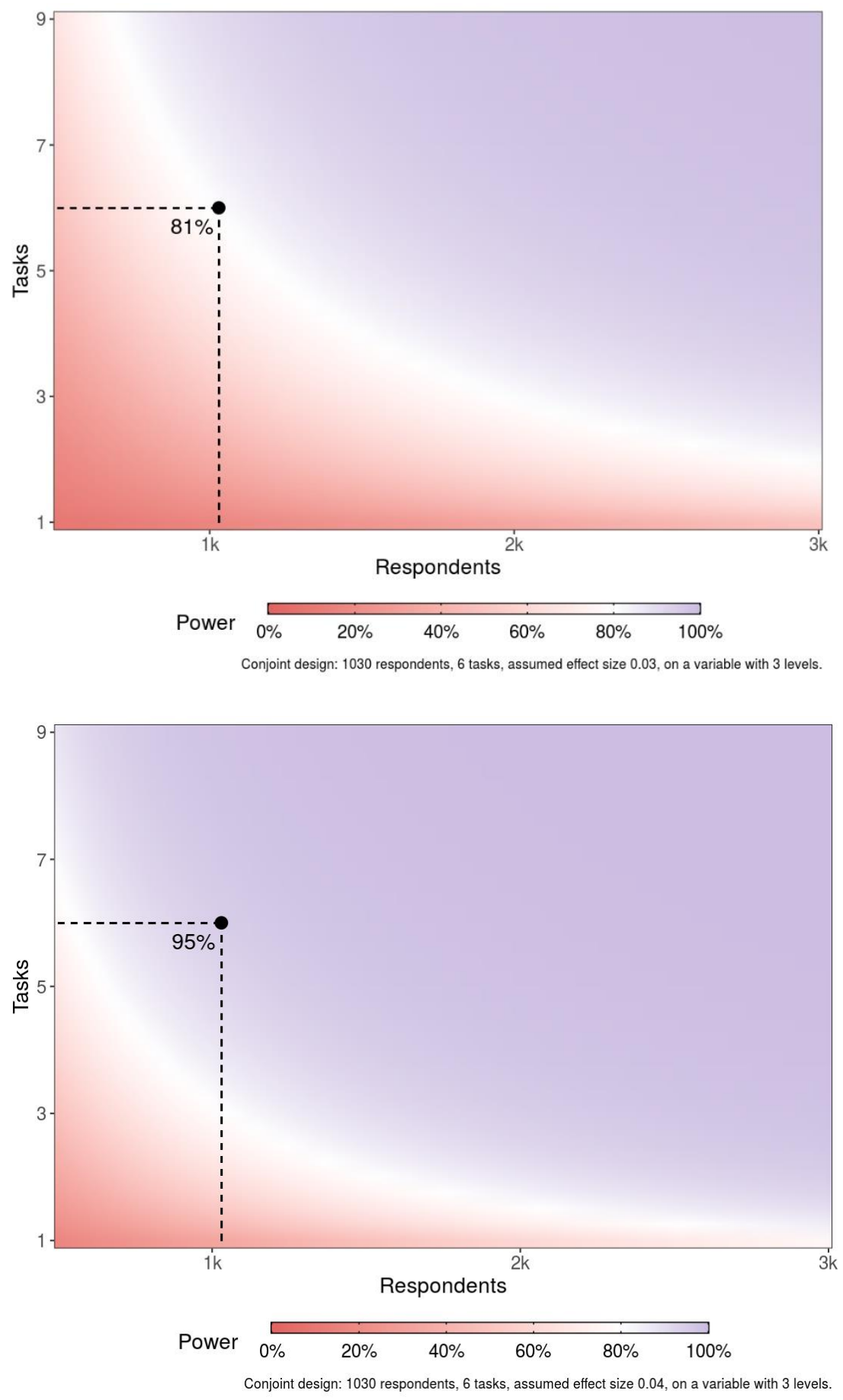
Lukac, M. \& Stefanelli, A. (2020). Conjoint Experiments: Power Analysis Tool. Retrieved from https://mblukac.shinyapps.io/conjoints-power-shiny/ 


\section{Appendix 3: Regression results}

The following table displays the regression results for all main analyses.

Table A2. Regression results.

\begin{tabular}{|c|c|c|c|c|c|c|}
\hline & AMCE & $\begin{array}{l}\text { Ideological } \\
\text { congruence }\end{array}$ & $\begin{array}{c}\text { Policy } \\
\text { congruence }\end{array}$ & Trust & $\begin{array}{l}\text { Satisfaction } \\
\text { democracy }\end{array}$ & $\begin{array}{c}\text { External } \\
\text { efficacy }\end{array}$ \\
\hline & $\begin{array}{c}B \\
(S E) \\
\end{array}$ & $\begin{array}{c}B \\
(S E) \\
\end{array}$ & $\begin{array}{c}B \\
(S E) \\
\end{array}$ & $\begin{array}{c}B \\
(S E) \\
\end{array}$ & $\begin{array}{c}B \\
(S E) \\
\end{array}$ & $\begin{array}{c}B \\
(S E) \\
\end{array}$ \\
\hline \multicolumn{7}{|c|}{ Violence against opposition (Ref. Condemns) } \\
\hline Fails to condemn & $\begin{array}{c}-0.132 * * * \\
(0.012)\end{array}$ & $\begin{array}{c}-0.134 * * * \\
(0.014)\end{array}$ & $\begin{array}{c}-0.121 * * * \\
(0.014)\end{array}$ & $\begin{array}{c}-0.089 * * * \\
(0.026)\end{array}$ & $\begin{array}{c}-0.084 * * * \\
(0.026)\end{array}$ & $\begin{array}{c}-0.128^{* * *} \\
(0.019)\end{array}$ \\
\hline Incites & $\begin{array}{c}-0.273^{* * *} \\
(0.013)\end{array}$ & $\begin{array}{c}-0.279 * * * \\
(0.014)\end{array}$ & $\begin{array}{c}-0.260 * * * \\
(0.014)\end{array}$ & $\begin{array}{c}-0.183^{* * *} * \\
(0.029)\end{array}$ & $\begin{array}{c}-0.173^{* * *} \\
(0.031)\end{array}$ & $\begin{array}{c}-0.246 * * * \\
(0.021)\end{array}$ \\
\hline \multicolumn{7}{|l|}{ Judicial officials (Ref respects) } \\
\hline Does not respect & $\begin{array}{c}-0.142^{* * *} \\
(0.010)\end{array}$ & $\begin{array}{c}-0.130 * * * \\
(0.011)\end{array}$ & $\begin{array}{c}-0.143^{* * *} * \\
(0.012)\end{array}$ & $\begin{array}{c}-0.104 * * * \\
(0.021)\end{array}$ & $\begin{array}{c}-0.103 * * * \\
(0.022)\end{array}$ & $\begin{array}{c}-0.139 * * * \\
(0.016)\end{array}$ \\
\hline Gender (ref. Female) & $\begin{array}{c}0.021 * * \\
(0.009)\end{array}$ & $\begin{array}{l}0.021^{*} \\
(0.011)\end{array}$ & $\begin{array}{l}0.018^{*} \\
(0.011)\end{array}$ & $\begin{array}{c}0.013 \\
(0.022)\end{array}$ & $\begin{array}{l}0.020 \\
(0.022)\end{array}$ & $\begin{array}{c}0.020 \\
(0.015)\end{array}$ \\
\hline \multicolumn{7}{|l|}{ Education (ref Low) } \\
\hline Intermediate & $\begin{array}{c}0.049^{* * * *} \\
(0.011)\end{array}$ & $\begin{array}{c}0.047 * * * \\
(0.013)\end{array}$ & $\begin{array}{c}0.046^{* * *} \\
(0.014)\end{array}$ & $\begin{array}{l}0.044^{*} \\
(0.025)\end{array}$ & $\begin{array}{l}0.047^{*} \\
(0.027)\end{array}$ & $\begin{array}{c}0.052^{* * *} \\
(0.018)\end{array}$ \\
\hline High & $\begin{array}{c}0.035^{* * * *} \\
(0.011)\end{array}$ & $\begin{array}{c}0.026^{* *} \\
(0.013)\end{array}$ & $\begin{array}{c}0.041 * * * \\
(0.013)\end{array}$ & $\begin{array}{c}0.056^{* *} \\
(0.024)\end{array}$ & $\begin{array}{l}0.046^{*} \\
(0.025)\end{array}$ & $\begin{array}{l}0.034 * * \\
(0.017)\end{array}$ \\
\hline \multicolumn{7}{|l|}{ Ideology (ref. Leftist) } \\
\hline Centrist & $\begin{array}{c}0.020 \\
(0.013)\end{array}$ & & $\begin{array}{c}0.033^{* *} \\
(0.015)\end{array}$ & $\begin{array}{c}0.002 \\
(0.029)\end{array}$ & $\begin{array}{c}0.019 \\
(0.030)\end{array}$ & $\begin{array}{c}0.008 \\
(0.021)\end{array}$ \\
\hline Rightist & $\begin{array}{c}0.011 \\
(0.012)\end{array}$ & & $\begin{array}{c}0.022 \\
(0.014)\end{array}$ & $\begin{array}{c}0.022 \\
(0.028)\end{array}$ & $\begin{array}{c}0.017 \\
(0.029)\end{array}$ & $\begin{array}{c}0.014 \\
(0.021)\end{array}$ \\
\hline \multicolumn{7}{|c|}{ Populism (ref ordinary citizens) } \\
\hline Political elites & $\begin{array}{c}-0.077 * * * \\
(0.012)\end{array}$ & $\begin{array}{c}-0.084 * * * \\
(0.014)\end{array}$ & $\begin{array}{c}-0.083^{* * *} \\
(0.014)\end{array}$ & $\begin{array}{c}-0.089 * * * \\
(0.027)\end{array}$ & $\begin{array}{c}-0.078^{* * *} \\
(0.028)\end{array}$ & $\begin{array}{c}-0.116^{* * * *} \\
(0.020)\end{array}$ \\
\hline Social groups & $\begin{array}{c}-0.051 * * * \\
(0.011)\end{array}$ & $\begin{array}{c}-0.048^{* * *} \\
(0.014)\end{array}$ & $\begin{array}{c}-0.063^{* * *} * \\
(0.013)\end{array}$ & $\begin{array}{c}-0.062^{* *} \\
(0.025)\end{array}$ & $\begin{array}{c}-0.081 * * * \\
(0.025)\end{array}$ & $\begin{array}{c}-0.062 * * * \\
(0.018)\end{array}$ \\
\hline \multicolumn{7}{|c|}{ Immigration policy (ref. Reduce) } \\
\hline Status quo & $\begin{array}{c}0.016 \\
(0.012)\end{array}$ & $\begin{array}{c}0.021 \\
(0.014)\end{array}$ & & $\begin{array}{c}-0.075^{* * *} \\
(0.025)\end{array}$ & $\begin{array}{c}-0.099 * * * \\
(0.028)\end{array}$ & $\begin{array}{c}-0.044 * * \\
(0.019)\end{array}$ \\
\hline Increase & $\begin{array}{c}-0.153^{* * *} \\
(0.014)\end{array}$ & $\begin{array}{c}-0.148^{* * *} \\
(0.016)\end{array}$ & & $\begin{array}{c}-0.289 * * * \\
(0.027)\end{array}$ & $\begin{array}{c}-0.326 * * * \\
(0.029)\end{array}$ & $\begin{array}{c}-0.243 * * * \\
(0.021)\end{array}$ \\
\hline \multicolumn{7}{|c|}{ Ideological congruence (ref mismatch) } \\
\hline Leftist & & $\begin{array}{c}0.123 * * * \\
(0.042)\end{array}$ & & & & \\
\hline Centrist & & $\begin{array}{c}0.008 \\
(0.044)\end{array}$ & & & & \\
\hline Rightist & & $\begin{array}{c}0.119 * * * \\
(0.044)\end{array}$ & & & & \\
\hline Fails to condemn\#Leftist & & $\begin{array}{c}0.011 \\
(0.034)\end{array}$ & & & & \\
\hline Fails to condemn\#Centrist & & $\begin{array}{c}0.119 * * * \\
(0.034)\end{array}$ & & & & \\
\hline Fails to condemn\#Rightist & & $\begin{array}{c}-0.076^{* *} \\
(0.031)\end{array}$ & & & & \\
\hline Incites\#Leftist & & $\begin{array}{c}0.003 \\
(0.033)\end{array}$ & & & & \\
\hline Incites\# Centrist & & $\begin{array}{l}0.059 * \\
(0.036)\end{array}$ & & & & \\
\hline Incites\#Rightist & & $\begin{array}{c}0.007 \\
(0.032)\end{array}$ & & & & \\
\hline Does not respect\#Leftist & & $\begin{array}{l}-0.024 \\
(0.029)\end{array}$ & & & & \\
\hline Does not respect\# Centrist & & $\begin{array}{l}-0.034 \\
(0.029)\end{array}$ & & & & \\
\hline Does not respect\#Rightist & & $\begin{array}{l}-0.041 \\
(0.026)\end{array}$ & & & & \\
\hline Male\#Leftist & & $\begin{array}{c}0.008 \\
(0.027)\end{array}$ & & & & \\
\hline Male\# Centrist & & $\begin{array}{c}0.046 \\
(0.028)\end{array}$ & & & & \\
\hline Male\#Rightist & & $\begin{array}{l}-0.042 \\
(0.027)\end{array}$ & & & & \\
\hline
\end{tabular}




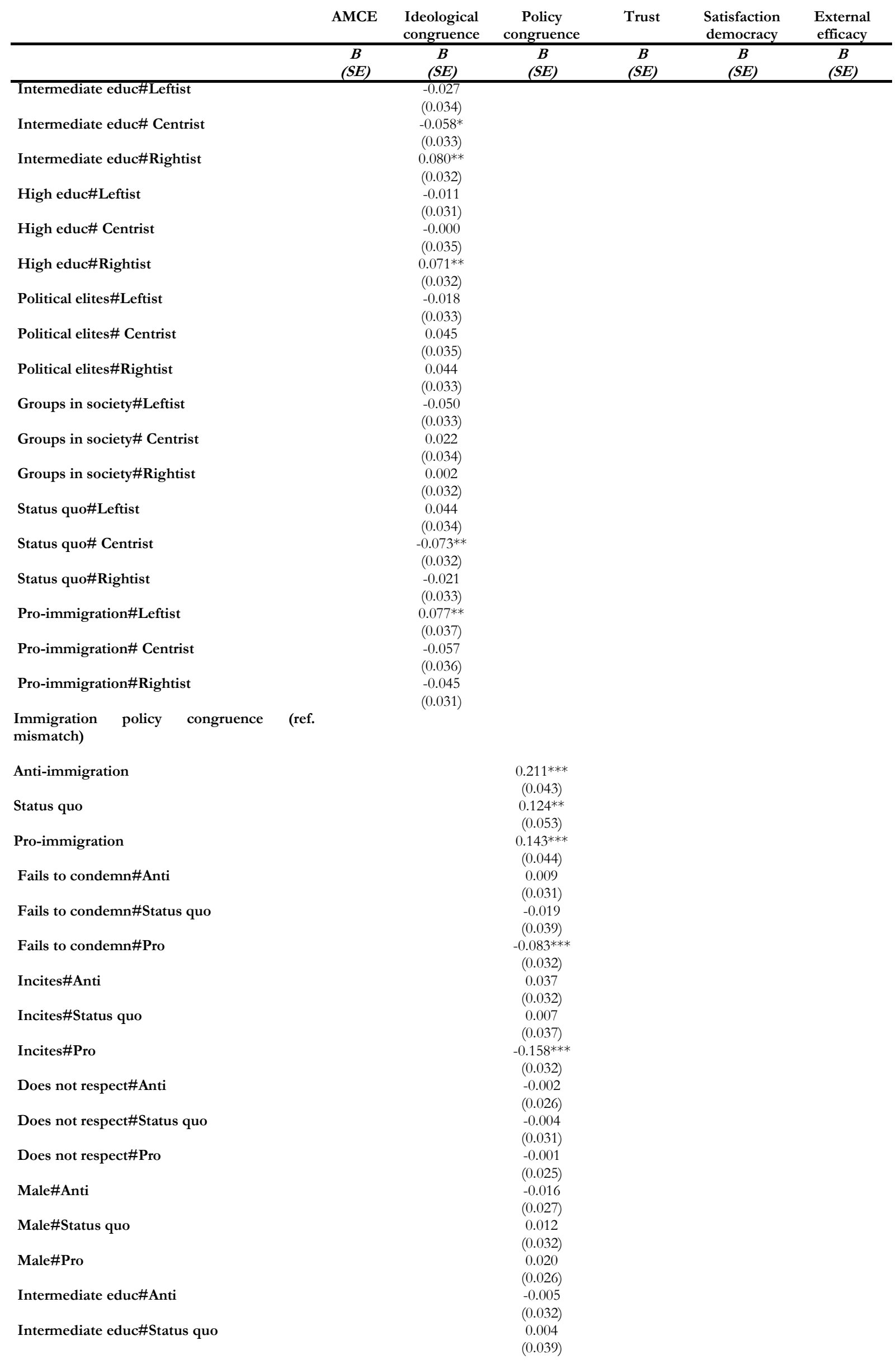




\begin{tabular}{|c|c|c|c|c|c|c|}
\hline & AMCE & $\begin{array}{l}\text { Ideological } \\
\text { congruence }\end{array}$ & $\begin{array}{c}\text { Policy } \\
\text { congruence }\end{array}$ & Trust & $\begin{array}{l}\text { Satisfaction } \\
\text { democracy }\end{array}$ & $\begin{array}{c}\text { External } \\
\text { efficacy }\end{array}$ \\
\hline & $\begin{array}{c}B \\
(S E)\end{array}$ & $\begin{array}{c}B \\
(S E)\end{array}$ & $\begin{array}{c}B \\
(S E)\end{array}$ & $\begin{array}{c}B \\
(S E)\end{array}$ & $\begin{array}{c}B \\
(S E)\end{array}$ & $\begin{array}{c}B \\
(S E)\end{array}$ \\
\hline Intermediate educ\#Pro & & & $\begin{array}{c}0.005 \\
(0.033)\end{array}$ & & & \\
\hline High educ\#Anti & & & $\begin{array}{c}0.024 \\
(0.033)\end{array}$ & & & \\
\hline High educ\#Status quo & & & $\begin{array}{l}-0.027 \\
(0.040)\end{array}$ & & & \\
\hline High educ\#Pro & & & $\begin{array}{l}-0.056^{*} \\
(0.033)\end{array}$ & & & \\
\hline Centrist\#Anti & & & $\begin{array}{c}-0.060^{* *} \\
(0.030)\end{array}$ & & & \\
\hline Centrist\#Status quo & & & $\begin{array}{l}-0.049 \\
(0.040)\end{array}$ & & & \\
\hline Centrist\#Pro & & & $\begin{array}{l}-0.030 \\
(0.034)\end{array}$ & & & \\
\hline Rightist\#Anti & & & $\begin{array}{l}-0.029 \\
(0.031)\end{array}$ & & & \\
\hline Rightist\#Status quo & & & $\begin{array}{l}-0.016 \\
(0.038)\end{array}$ & & & \\
\hline Rightist\#Pro & & & $\begin{array}{l}-0.047 \\
(0.034)\end{array}$ & & & \\
\hline Political elites\#Anti & & & $\begin{array}{l}-0.022 \\
(0.034)\end{array}$ & & & \\
\hline Political elites\#Status quo & & & $\begin{array}{c}0.014 \\
(0.037)\end{array}$ & & & \\
\hline Political elites\#Pro & & & $\begin{array}{l}0.055^{*} \\
(0.032)\end{array}$ & & & \\
\hline Groups in society\#Anti & & & $\begin{array}{l}0.060^{*} \\
(0.031)\end{array}$ & & & \\
\hline Groups in society\#Status quo & & & $\begin{array}{c}0.007 \\
(0.038)\end{array}$ & & & \\
\hline Groups in society\#Pro & & & $\begin{array}{c}0.015 \\
(0.030)\end{array}$ & & & \\
\hline Political trust (ref Disaffected) & & & & & & \\
\hline Intermediate & & & & $\begin{array}{c}0.013 \\
(0.047)\end{array}$ & & \\
\hline Satisfied & & & & $\begin{array}{l}-0.058 \\
(0.045)\end{array}$ & & \\
\hline Fails to condemn\#Intermediate trust & & & & $\begin{array}{l}-0.032 \\
(0.032)\end{array}$ & & \\
\hline Fails to condemn\#Satisfied & & & & $\begin{array}{c}-0.071 * * \\
(0.031)\end{array}$ & & \\
\hline Incites\#Intermediate trust & & & & $\begin{array}{c}-0.079 * * \\
(0.036)\end{array}$ & & \\
\hline Incites\#Satisfied & & & & $\begin{array}{c}-0.143^{* * *} \\
(0.035)\end{array}$ & & \\
\hline Does not respect\#Intermediate trust & & & & $\begin{array}{r}-0.023 \\
(0.026)\end{array}$ & & \\
\hline Does not respect\#Satisfied & & & & $\begin{array}{c}-0.070^{* * *} \\
(0.026)\end{array}$ & & \\
\hline Male\#Intermediate trust & & & & $\begin{array}{c}0.011 \\
(0.026)\end{array}$ & & \\
\hline Male\#Satisfied & & & & $\begin{array}{c}0.009 \\
(0.026)\end{array}$ & & \\
\hline Intermediate educ\#Intermediate trust & & & & $\begin{array}{l}-0.030 \\
(0.030)\end{array}$ & & \\
\hline Intermediate educ\#Satisfied & & & & $\begin{array}{c}0.037 \\
(0.030)\end{array}$ & & \\
\hline High educ\#Intermediate trust & & & & $\begin{array}{l}-0.036 \\
(0.030)\end{array}$ & & \\
\hline High educ\#Satisfied & & & & $\begin{array}{l}-0.014 \\
(0.029)\end{array}$ & & \\
\hline Centrist\# Intermediate trust & & & & $\begin{array}{c}0.000 \\
(0.036)\end{array}$ & & \\
\hline Centrist\#Satisfied & & & & $\begin{array}{c}0.039 \\
(0.035)\end{array}$ & & \\
\hline Rightist\# Intermediate trust & & & & $\begin{array}{l}-0.028 \\
(0.035)\end{array}$ & & \\
\hline Rightist\#Satisfied & & & & $\begin{array}{l}-0.004 \\
(0.034)\end{array}$ & & \\
\hline Political elites\# Intermediate trust & & & & $\begin{array}{l}-0.000 \\
(0.033)\end{array}$ & & \\
\hline Political elites\#satisfied & & & & $\begin{array}{c}0.028 \\
(0.032)\end{array}$ & & \\
\hline
\end{tabular}




\begin{tabular}{|c|c|c|c|c|c|c|}
\hline & AMCE & $\begin{array}{l}\text { Ideological } \\
\text { congruence }\end{array}$ & $\begin{array}{c}\text { Policy } \\
\text { congruence }\end{array}$ & Trust & $\begin{array}{c}\text { Satisfaction } \\
\text { democracy }\end{array}$ & $\begin{array}{c}\text { External } \\
\text { efficacy }\end{array}$ \\
\hline & $\begin{array}{c}B \\
(S E)\end{array}$ & $\begin{array}{c}B \\
(S E)\end{array}$ & $\begin{array}{c}B \\
(S E)\end{array}$ & $\begin{array}{c}B \\
(S E)\end{array}$ & $\begin{array}{c}B \\
(S E)\end{array}$ & $\begin{array}{c}B \\
(S E)\end{array}$ \\
\hline Groups in society\# Intermediate trust & & & & $\begin{array}{c}0.009 \\
(0.031)\end{array}$ & & \\
\hline Groups in society\#Satisfied & & & & $\begin{array}{c}0.020 \\
(0.030)\end{array}$ & & \\
\hline Status quo\#Intermediate trust & & & & $\begin{array}{c}0.073^{* *} \\
(0.032)\end{array}$ & & \\
\hline Status quo\#Satisfied & & & & $\begin{array}{c}0.147^{* * *} * \\
(0.031)\end{array}$ & & \\
\hline Pro-immigration\#Intermediate trust & & & & $\begin{array}{c}0.104 * * * \\
(0.036)\end{array}$ & & \\
\hline Pro-immigration\#Satisfied & & & & $\begin{array}{c}0.226^{* * *} * \\
(0.034)\end{array}$ & & \\
\hline
\end{tabular}

Satisfaction w democracy (ref Disaffected)

Intermediate satisfaction

0.010

(0.067)

Satisfied

$-0.050$

(0.046)

Does not respect\# Intermediate satisfaction

0.018

(0.036)

$-0.058^{* *}$

Does not respect\#Satisfied

Fails to condemn\# Intermediate satisfaction

(0.025)

$-0.010$

(0.045)

Fails to condemn\#Satisfied

$-0.064 * *$

(0.030)

Incites\# Intermediate satisfaction

(0.050)

$-0.134 * * *$

(0.034)

Male\# Intermediate satisfaction

$-0.006$

(0.036)

0.004

Male\#Satisfied

Intermediate educ\# Intermediate satisfaction

$(0.025)$

$-0.060$

$(0.043)$

Intermediate educ\#Satisfied

High educ\# Intermediate satisfaction

0.010

(0.030)

$-0.033$

(0.040)

High educ\#Satisfied

Centrist\# Intermediate satisfaction

Centrist\#Satisfied

Rightist\# Intermediate satisfaction

Rightist\#Satisfied

Political elites\# Intermediate satisfaction

Political elites\#Satisfied

Groups in society\# Intermediate satisfaction

$-0.010$

(0.028)

$-0.049$

$(0.049)$

0.009

(0.034)

$-0.003$

(0.047)

$-0.007$

$(0.033)$

$-0.054$

$(0.044)$

0.009

(0.031)

0.002

(0.043)

0.042

(0.029)

$0.096 * *$

(0.048)

$0.147 * * *$

(0.031)

$0.102^{*}$

(0.054)

Pro-immigration\# Intermediate satisfaction

Pro-immigration\#Satisfied

(0.033)

External efficacy (Ref disaffected)

Intermediate satisfaction

Satisfied

Does not respect\# Intermediate satisfaction

Does not respect\#Satisfied 


\begin{tabular}{|c|c|c|c|c|c|c|}
\hline & AMCE & $\begin{array}{l}\text { Ideological } \\
\text { congruence }\end{array}$ & $\begin{array}{c}\text { Policy } \\
\text { congruence }\end{array}$ & Trust & $\begin{array}{c}\text { Satisfaction } \\
\text { democracy }\end{array}$ & $\begin{array}{c}\text { External } \\
\text { efficacy }\end{array}$ \\
\hline & $\begin{array}{c}B \\
(S E)\end{array}$ & $\begin{array}{c}B \\
(S E) \\
\end{array}$ & $\begin{array}{c}B \\
(S E)\end{array}$ & $\begin{array}{c}B \\
(S E)\end{array}$ & $\begin{array}{c}B \\
(S E)\end{array}$ & $\begin{array}{c}B \\
(S E)\end{array}$ \\
\hline Fails to condemn\#Intermediate satisfaction & & & & & & $\begin{array}{l}(0.028) \\
-0.005 \\
(0.026)\end{array}$ \\
\hline Fails to condemn\#Satisfied & & & & & & $\begin{array}{l}-0.005 \\
(0.033)\end{array}$ \\
\hline Incites\#Intermediate satisfaction & & & & & & $\begin{array}{l}-0.019 \\
(0.028)\end{array}$ \\
\hline Incites\#Satisfied & & & & & & $\begin{array}{c}-0.100^{* * *} \\
(0.035)\end{array}$ \\
\hline Male\# Intermediate satisfaction & & & & & & $\begin{array}{c}0.008 \\
(0.020)\end{array}$ \\
\hline Male\#Satisfied & & & & & & $\begin{array}{l}-0.008 \\
(0.027)\end{array}$ \\
\hline Intermediate educ\#Intermediate satisfaction & & & & & & $\begin{array}{l}-0.015 \\
(0.024)\end{array}$ \\
\hline Intermediate educ\#Satisfied & & & & & & $\begin{array}{c}0.011 \\
(0.033)\end{array}$ \\
\hline High educ\#Intermediate satisfaction & & & & & & $\begin{array}{l}-0.020 \\
(0.023)\end{array}$ \\
\hline High educ\#Satisfied & & & & & & $\begin{array}{c}0.050 \\
(0.032)\end{array}$ \\
\hline Centrist\# Intermediate satisfaction & & & & & & $\begin{array}{c}0.006 \\
(0.028)\end{array}$ \\
\hline Centrist\#Satisfied & & & & & & $\begin{array}{c}0.046 \\
(0.035)\end{array}$ \\
\hline Rightist\# Intermediate satisfaction & & & & & & $\begin{array}{l}-0.012 \\
(0.028)\end{array}$ \\
\hline Rightist\#Satisfied & & & & & & $\begin{array}{c}0.012 \\
(0.036)\end{array}$ \\
\hline Political elites\# Intermediate satisfaction & & & & & & $\begin{array}{c}0.053^{* *} \\
(0.026)\end{array}$ \\
\hline Political elites\#Satisfied & & & & & & $\begin{array}{c}0.081 * * * \\
(0.031)\end{array}$ \\
\hline Groups in society\# Intermediate satisfaction & & & & & & $\begin{array}{c}0.024 \\
(0.025)\end{array}$ \\
\hline Groups in society\#Satisfied & & & & & & $\begin{array}{c}0.004 \\
(0.032)\end{array}$ \\
\hline Status quo\#Intermediate satisfaction & & & & & & $\begin{array}{c}0.080^{* * *} \\
(0.026)\end{array}$ \\
\hline Status quo\#Satisfied & & & & & & $\begin{array}{c}0.129 * * * \\
(0.033)\end{array}$ \\
\hline Pro-immigration\#Intermediate satisfaction & & & & & & $\begin{array}{c}0.113^{* * *} * \\
(0.030)\end{array}$ \\
\hline Pro-immigration\#Satisfied & & & & & & $\begin{array}{c}0.217 \text { *** } \\
(0.038)\end{array}$ \\
\hline Constant & $\begin{array}{c}0.746^{* * * *} \\
(0.017)\end{array}$ & $\begin{array}{c}0.726^{* * *} \\
(0.018)\end{array}$ & $\begin{array}{c}0.650 * * * \\
(0.018)\end{array}$ & $\begin{array}{c}0.766^{* * * *} \\
(0.038)\end{array}$ & $\begin{array}{c}0.779 * * * \\
(0.042)\end{array}$ & $\begin{array}{c}0.803^{* * *} * \\
(0.026)\end{array}$ \\
\hline Observations & 12360 & 12360 & 12360 & 12360 & 12360 & 12360 \\
\hline
\end{tabular}




\section{Appendix 4: Voting for leaders}

The following show all results for the follow-up question where respondents were asked if they would also vote for the leader profile they selected.

Figure A2. Voting for selected leader
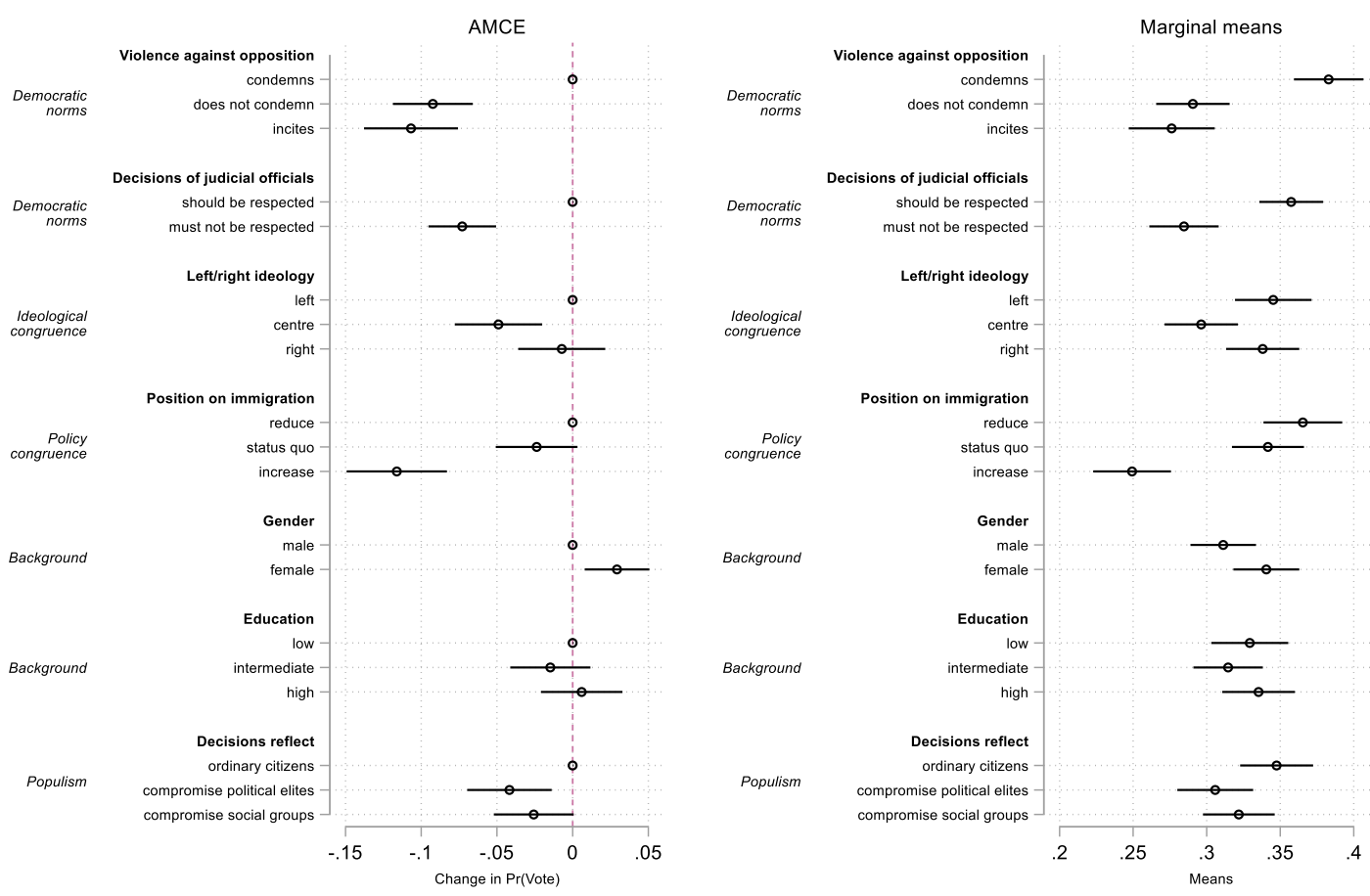
Figure A3. Congruence and voting for selected leader
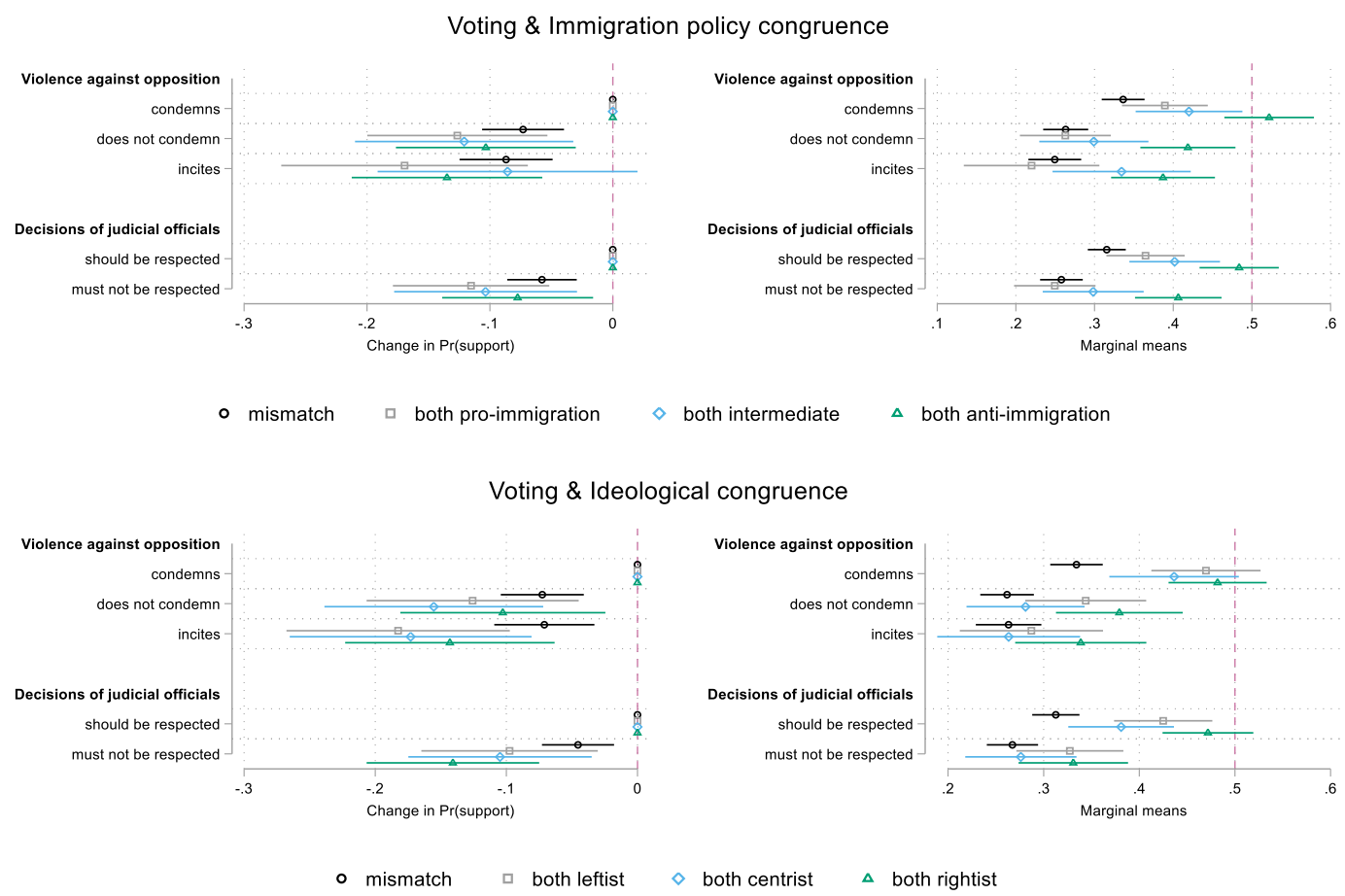

Figure A4 Disaffection and voting for selected leader 
Political trust
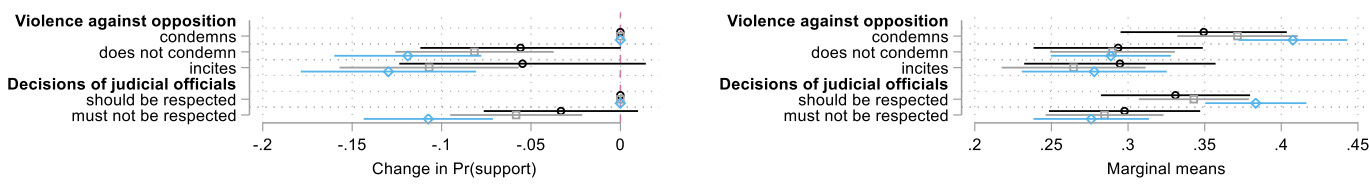

Satisfaction with democracy
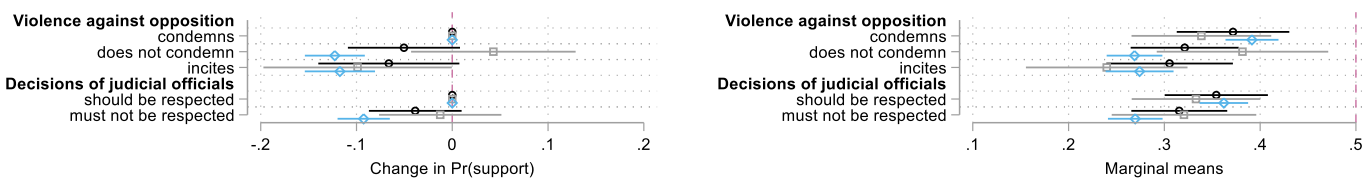

External political efficacy
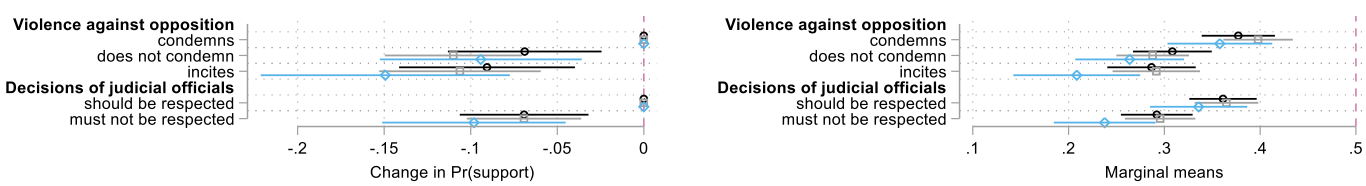

- Dissatisfied $\square$ Intermediate $\diamond$ Satisfied

\section{Appendix 5: Differences across rounds and profile ordering}

Figure A5 shows the differences across the six rounds and the ordering of the profiles (left/right).

Figure A5 Differences across rounds and left/right profile 

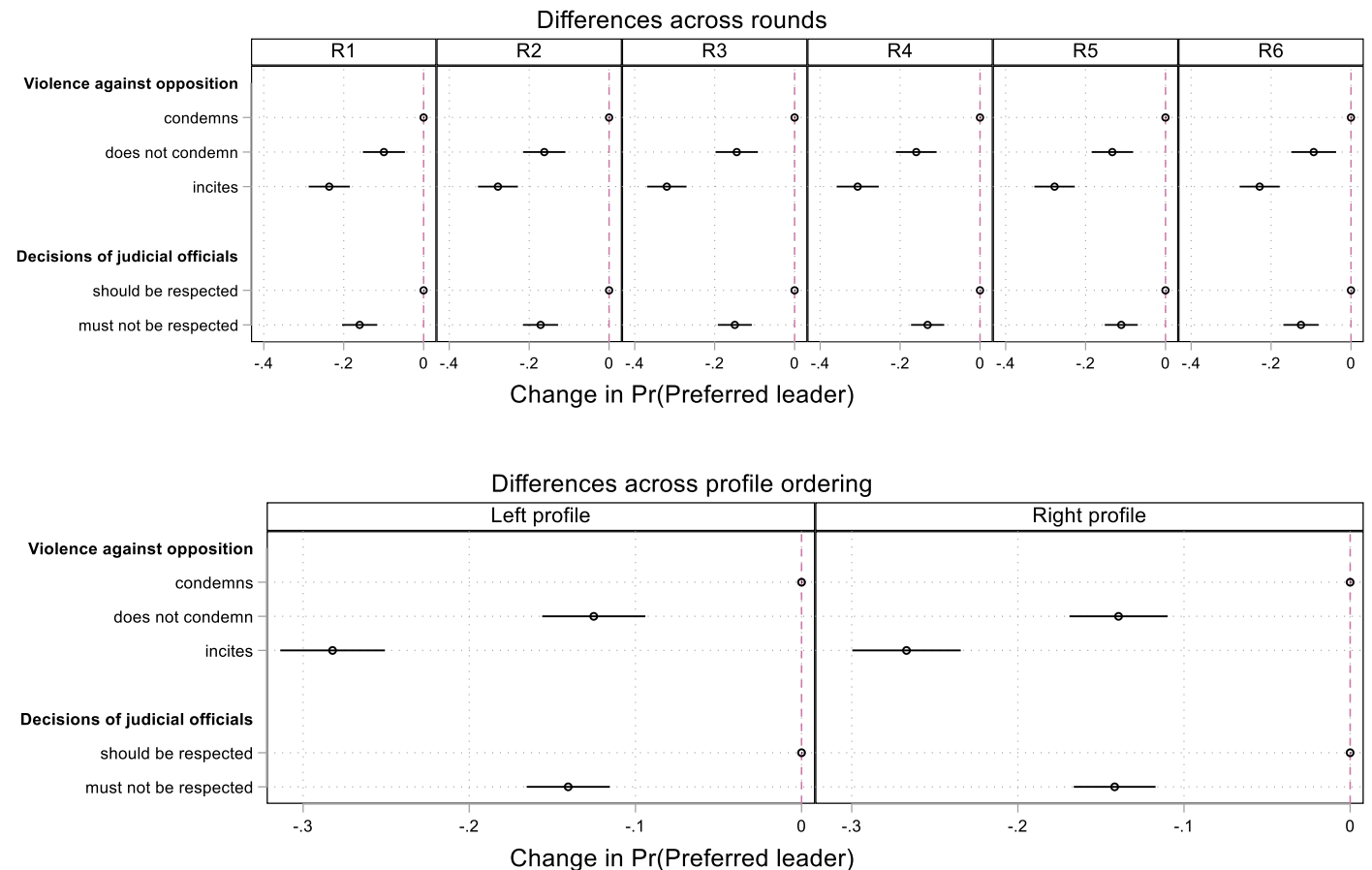


\section{Appendix 6: Deviations from preregistration}

This study was preregistered at www.doi.org/10.17605/OSF.IO/F6GR4

We here note all deviations from the preregistration that occurred during the writing up of results and the peer-review process. The changes are noted under the corresponding header of the preregistration.

\section{Hypotheses}

- "Candidate" was changed to "leader" in H2a, H2b, H3a and H3b to signal that the study is not confined to an electoral context, but the content remain identical.

- H2a and H2b: It was clarified that the expectation is that effects are weaker when the leader's policy position is congruent with the respondent's policy position. The content is identical.

- H3a and H3b: It was clarified that the expectation was that effects are weaker when the leader's ideological position is congruent with the respondent's ideological position. The content is identical.

- H4a and H4b: to avoid conceptual ambiguity, we now refer to political disaffection rather than political dissatisfaction. The substantial contents of the hypotheses are identical.

- H5a and H5b on generational differences were excluded from this article due to a lack of space. The research question will now form the basis of a separate research paper currently in preparation.

\section{Sample size}

The sample target was 1000 respondents, but in the end the study included 1030 respondents performing six tasks and a maximum of three attribute. This entails that we can estimate relative small effects sizes of $\mathrm{AMCE}=0.03$ with an estimated statistical power of $81 \%$, and effects sizes of $\mathrm{AMCE}=0.04$ with a statistical power of $95 \%$, as shown in the appendix (Lukac and Stefanelli 2020). For the subgroup analyses, the number of respondents were fewer than expected for the congruence variables since the distribution was severely skewed.

\section{Transformations of variables}

The construction of the Ideological and policy congruence variables was inadequately described in the preregistration and the registered transformations do not make it possible to address the 
hypotheses. In the study, respondents' classification was matched with the position of the profile in question as follows:

Ideological congruence: The variable was constructed based on the respondents' score on the 0-10 ideological score and the position of the profile. The variable has four categories: 1) Mismatch (respondent and profile had different ideological positions, 66.7\%); 2) Both leftist (Profile was leftist and respondent indicated 0-4 on the scale, 11.0\%); 3) Both centrist (profile was centrist and respondent chose 5 on the scale, 10.4\%); and 4) Both rightist (Profile was rightist and respondent chose 6-10 on the scale, 11.9\%).

Immigration congruence: The variable was constructed based on the profile position on immigration and an index ranging from 0-8 based on two questions where respondents indicated their attitudes to immigrant workers and asylum seekers on five-point Likert scales (higher scores indicates more positive attitudes to immigration). This also has four categories: 1) Mismatch (respondent and profile had different attitudes to immigration, 66.7\%); 2) Both proimmigration (respondent promised to increase number of immigrants and respondent scored 58 on the index, $12.4 \%$ ); 3) Both intermediate (profile promised to maintain status quo and respondent scored 4 on the index, 8.9\%); and 4) Both anti-immigration (Profile promised to lower number of immigrants and respondent scored 0-3 on the index, 12.1\%).

\section{Analysis}

In addition to the conjoint experiment, we begin the empirical analysis with a descriptive analysis of attitudes to various democratic norms. 


\section{Appendix 7: Candidate choice example}

(1/6) Valitse mieleisesi pääministeriehdokas alla olevista vaihtoehdoista:

\begin{tabular}{|c|c|c|}
\hline & Ehdokas 1 & Ehdokas 2 \\
\hline Sukupuoli & Mies & Nainen \\
\hline Koulutus & Keskiasteen tutkinto & Yliopistotutkinto \\
\hline Poliittiset näkemykset & Keskusta & Keskusta \\
\hline On sitä mieltä, että... & $\begin{array}{l}\text {...oikeusviranomaisten päätöksiä tulee } \\
\text { kunnioittaa, vaikka ne vaikuttaisivat } \\
\text { kielteisesti hänen puolueensa ajamaan } \\
\text { politiikkaan. }\end{array}$ & $\begin{array}{l}\text {...El tarvitse kunnioittaa } \\
\text { oikeusviranomaisten päätöksiä, jos } \\
\text { ne vaikuttavat kielteisesti hänen } \\
\text { puolueensa ajamaan politiikkaan. }\end{array}$ \\
\hline $\begin{array}{l}\text { Suhtautuminen poliittiseen } \\
\text { oppositioon }\end{array}$ & $\begin{array}{l}\text { Ei tuomitse fyysisiä hyökkäyksiä } \\
\text { oppositiopoliitikkoja kohtaan. }\end{array}$ & $\begin{array}{l}\text { Ei tuomitse fyysisiä hyökkäyksiä } \\
\text { oppositiopoliitikkoja kohtaan. }\end{array}$ \\
\hline $\begin{array}{l}\text { Lupaa painottaa poliittisissa } \\
\text { päätöksissään... }\end{array}$ & ...tavallisten inmisten asiaa. & ...tavallisten inmisten asiaa. \\
\hline Suhtautuminen maahanmuuttoon & $\begin{array}{l}\text { Lupaa vähentää maahanmuuttajien } \\
\text { määrää Suomessa. }\end{array}$ & $\begin{array}{l}\text { Lupaa lisätä maahanmuuttajien } \\
\text { määrää Suomessa. }\end{array}$ \\
\hline
\end{tabular}




\section{Appendix 8: Original questionnaire}

Q1 Kiitos, että osallistutte tähän Åbo Akademin tutkijoiden tekemään tutkimukseen. Aineistoa

käytetään ainoastaan tutkimuskäyttöön.

Tutkimus tarkastelee suhtautumista poliittisiin päättäjiin ja demokratiaan Suomessa.

Kysymme mielipiteitänne näistä asioista.

Kyselyyn vastaaminen kestää noin 5-10 minuuttia.

Ensiksi haluamme kysyä muutaman kysymyksen sinusta. Valitse jokaisen kysymyksen osalta se vaihtoehto, joka parhaiten kuvaa sinua.

Q3 Kuinka vanha olet?

Q4 Sukupuolesi?

Nainen

Mies

Muu/en halua sanoa

Q5 Missä sinä asut?

Maakunta

Kunta 
Q6 Mikä on korkein suorittamasi kouluaste tai tutkinto?

Vähemmän kuin peruskoulu (luokat 1-9)

Peruskoulu (luokat 1-9)

Ammattitutkinto

Ylioppilastutkinto

Ylempi opistoaste tai ammattikorkeakoulututkinto

Yliopistotutkinto

Muu/en osaa sanoa

Q7 Kuinka suuret ovat keskimäärin kotitaloutesi yhteenlasketut vuositulot veroja vähentämättä (=bruttotulot) mukaanlaskien veronalaiset sosiaalietuudet?

Q8 Seuraavaksi kysymme mielipiteitäsi politiikasta. Valitse jokaisen kysymyksen kohdalla se vaihtoehto, joka on lähimpänä mielipidettäsi.

Q9 Kuinka kiinnostunut olet politiikasta?
En lainkaan kiinnostunut
Vain vähän kiinnostunut
Jonkin verran kiinnostunut
Hyvin kiinnostunut 
Q10 Kuinka tyytyväinen olet demokratian toimivuuteen Suomessa?

En ollenkaanErittäin tyytyväinen

tyytyväinen

Q11 Mitä mieltä olet seuraavista väittämistä?

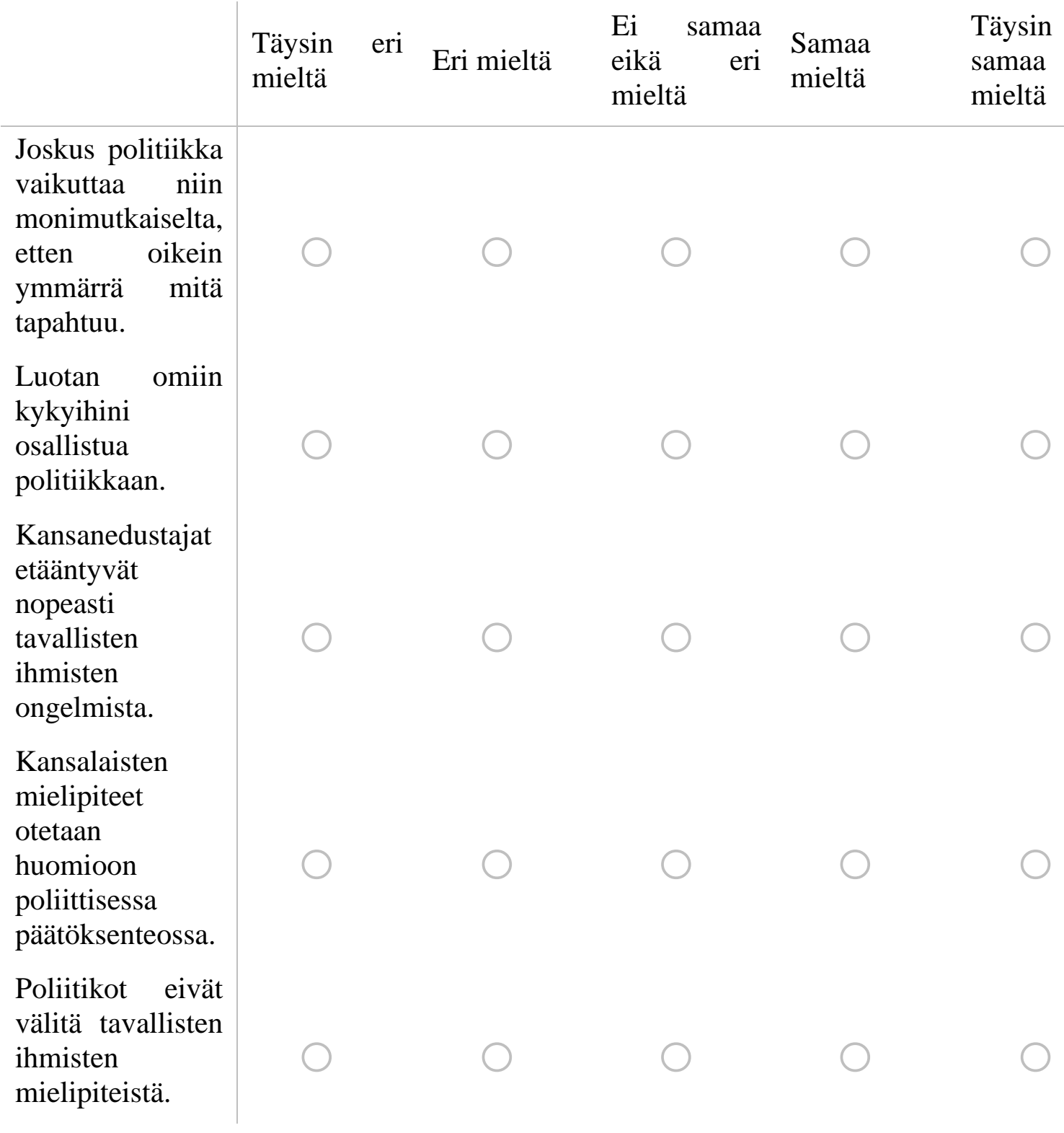


Q12 Kuinka paljon luotat tai et luota seuraaviin tahoihin? Arvioi kutakin tahoa asteikolla nollasta kymmeneen, missä 0 on "en luota ollenkaan" ja 10 "luotan täysin".

\begin{tabular}{|c|c|c|c|c|c|c|c|c|c|c|}
\hline & $\begin{array}{l}\text { En luota } \\
\text { ollenkaan } 1 \\
0\end{array}$ & 2 & 3 & 4 & 5 & 6 & 7 & 8 & 9 & $\begin{array}{l}\text { Luotan } \\
\text { täysin } \\
10\end{array}$ \\
\hline Eduskunta & 0 & & & & & & & & & \\
\hline $\begin{array}{l}\text { Suomen } \\
\text { poliittiset } \\
\text { puolueet }\end{array}$ & C & & & & & & & & & \\
\hline $\begin{array}{l}\text { Suomen hallitus } \\
\text { (valtioneuvosto) }\end{array}$ & $C$ & & & & & & & & & \\
\hline $\begin{array}{l}\text { Suomalaiset } \\
\text { poliitikot }\end{array}$ & D & & & & & & & & & \\
\hline
\end{tabular}

Q13 Nykyisin monet jättävät syystä tai toisesta äänestämättä vaaleissa. Jätitkö sinä edellisissä kevään 2019 eduskuntavaaleissa äänestämättä?

Kyllä

En

En halua sanoa / En osaa sanoa

Q14 Katsotko yleensä olevasi lähellä jotakin poliittista puoluetta?

Kyllä

En

Q15 Mitä puoluetta?

Kansallinen Kokoomus (KOK) 
Suomen Sosialidemokraattinen Puolue (SDP)

Perussuomalaiset (PS)

Suomen Keskusta (KESK)

Vasemmistoliitto (VAS)

Vihreä liitto (VIHR)

Suomen ruotsalainen kansanpuolue (RKP)

Suomen Kristillisdemokraatit (KD)

Jotain muuta puoluetta

Q16 Politiikassa puhutaan joskus vasemmistosta ja oikeistosta. Käyttämällä asteikkoa, jossa nolla tarkoittaa eniten vasemmalla ja kymmenen eniten oikealla, mihin sijoittaisit itsesi?

Q17 Miten suhtaudut työperäiseen maahanmuuttoon Suomeen?

Käytä vastaamisessa asteikkoa yhdestä viiteen (1-5), jossa yksi tarkoittaa "erittäin kielteisesti", kolme "neutraalisti" ja viisi "erittäin myönteisesti".

Q18 Miten suhtaudut siihen, että Suomeen otetaan lisää turvapaikanhakijoita? 
Käytä vastaamisessa asteikkoa yhdestä viiteen (1-5), jossa yksi tarkoittaa "erittäin kielteisesti", kolme "neutraalisti" ja viisi "erittäin myönteisesti".

Q19 Seuraavassa on lueteltu eräitä ehdotuksia koskien Suomen tulevaisuuden suuntaa. Mitä mieltä olet näistä ehdotuksista? Käytä vastaamisessa asteikkoa nollasta kymmeneen (0-10), jossa nolla tarkoittaa "erittäin huono ehdotus", viisi "ei hyvä eikä huono ehdotus" ja kymmenen "erittäin hyvä ehdotus".

$$
\begin{array}{llllcllllll}
\begin{array}{l}
\text { Erittäin } \\
\text { ehdotus }
\end{array} & \multicolumn{4}{c}{\begin{array}{c}
\text { huonoEi hyvä eikä huonoErittäin } \\
\text { ehdotus }
\end{array}} & \multicolumn{4}{c}{\text { hyvä }} \\
0 & 1 & 2 & 3 & 4 & 5 & 6 & 7 & 8 & 9 & 10
\end{array}
$$

\begin{tabular}{l|l|l|}
\hline $\begin{array}{l}\text { Monikulttuurinen Suomi, jossa } \\
\text { suhtaudutaan suvaitsevaisesti muista maista } \\
\text { tuleviin ihmisiin }\end{array}$ & \\
\hline $\begin{array}{l}\text { Suomi, jossa kristilliset arvot ovat } \\
\text { suuremmassa roolissa }\end{array}$ \\
\hline $\begin{array}{l}\text { Suomi, jossa suomenruotsalaisten } \\
\text { erityisasema otetaan huomioon }\end{array}$ \\
\hline $\begin{array}{l}\text { Suomi, jossa vahvistetaan seksuaalisten } \\
\text { vähemmistöjen oikeuksia }\end{array}$ \\
$\begin{array}{l}\text { Suomi, jossa maahanmuutto on } \\
\text { laajamittaisempaa }\end{array}$ \\
\hline
\end{tabular}

Q20 Ihmisillä on erilaisia näkemyksiä siitä, että minkälaisen pääministerin he haluaisivat ihannetilanteessa johtavan Suomea. Ihmisillä voi olla myös erilaisia odotuksia liittyen pääministerin persoonallisuuspiirteisiin, mielipiteisiin ja käyttäytymiseen. Seuraavassa osiossa haluamme tietää lisää siitä, minkä tyyppinen henkilö sopisi mielestäsi parhaiten Suomen pääministeriksi. Esitämme seuraavaksi erilaisia kuvauksia mahdollisista pääministeriehdokkaista. Kuvaukset sisältävät tietoa eri henkilöiden taustasta ja poliittisista mielipiteistä.

Sinulle näytetään kuusi paria mahdollisista pääministeriehdokkaista. Pyydämme sinua 
valitsemaan jokaisen parin jälkeen sen ehdokkaan, joka sopisi mielestäsi parhaiten Suomen pääministeriksi.

Lue jokaisen ehdokkaan kuvailu huolellisesti ennen kuin teet päätöksesi.

Q21 (1/6) Valitse mieleisesi pääministeriehdokas alla olevista vaihtoehdoista:

[Conjoint pairs]

Q22 Äänestäisitkö tätä ehdokasta vaaleissa?

Kyllä

En

Q23 (2/6) Valitse mieleisesi pääministeriehdokas alla olevista vaihtoehdoista:

[Conjoint pairs]

Q24 Äänestäisitkö tätä ehdokasta vaaleissa?

Kyllä

En 
Q25 (3/6) Valitse mieleisesi pääministeriehdokas alla olevista vaihtoehdoista:

[Conjoint pairs]

Q26 Äänestäisitkö tätä ehdokasta vaaleissa?

Kyllä

En

Q27 (4/6) Valitse mieleisesi pääministeriehdokas alla olevista vaihtoehdoista:

[Conjoint pairs] Q28 Äänestäisitkö tätä ehdokasta vaaleissa?

Kyllä

En

Q29 (5/6) Valitse mieleisesi pääministeriehdokas alla olevista vaihtoehdoista:

[Conjoint pairs]

Q30 Äänestäisitkö tätä ehdokasta vaaleissa?

Kyllä

En 
Q31 (6/6) Valitse mieleisesi pääministeriehdokas alla olevista vaihtoehdoista:

[Conjoint pairs]

Q32 Äänestäisitkö tätä ehdokasta vaaleissa?

Kyllä

En

Q33

Lopuksi haluaisimme kysyä suhtautumisestasi demokratiaan poliittisena järjestelmänä.

Q34 Mitä mieltä olet seuraavasta väittämästä? 
Demokratialla voi

olla ongelmansa, mutta se on parempi

kuin muut

hallitusmuodot.

Demokratia ei ole tehokas

hallitusmuoto, ja olisi parempi, että Suomea johtaisi vahva johtaja, jonka ei tarvitsisi välittää vaaleista.

On tärkeää, että Suomessa toimii vapaa ja poliittisesti riippumaton media.

Kansalaisten oikeutta poliittiseen osallistumiseen ei tulisi rajoittaa.

Oikeuslaitosta kohtaan ei tule kohdistaa poliittista painostusta.

Poliitikkojen tulisi kohdella toisiaan kunnioittavasti poliittisista erimielisyyksistä huolimatta. 


\section{Guardians of Democracy, English translation}

Q1 Thank you for participating in this study by Åbo Akademi University researchers. The material is used for research purposes only.

The study examines attitudes towards political decision-makers and democracy in Finland. In the following, we will ask your opinions on these matters.

It takes about 5-10 minutes to answer the survey.

First, we want to ask a few questions about you. For each question, choose the option that best describes you.

Q3 How old are you?

Q4 Your gender?

Female

Male

Other/I can’t say

Q5 Where do you live?

Region

Municipality

Q6 What is the highest level of education or degree you have completed?

Less than primary school (grades 1-9)

Primary school (grades 1-9)

Vocational training

Matriculation examination

Master's degree or polytechnic degree

University degree

Other/I can't say 
Q7 What is the average total annual income of your household before taxes (= gross income) including taxable social benefits?

Next, we ask your opinions on politics. For each question, select the option that is closest to your opinion.

Q9 How interested are you in politics?

Not at all interested

Just a little interested

Somewhat interested

Very interested

Q10 How satisfied are you with the functioning of democracy in Finland?

Q11 What do you think about the following statements?

\begin{tabular}{l|l|l} 
Completely & Disagree & $\begin{array}{l}\text { Neither agree } \\
\text { nor disagree } \\
\text { disagree }\end{array}$ \\
\hline $\begin{array}{l}\text { Sometimes } \\
\text { politics seems } \\
\text { so complicated } \\
\text { that I don't } \\
\text { really } \\
\text { understand } \\
\text { what's going on. }\end{array}$ \\
$\begin{array}{l}\text { I trust in my } \\
\text { own ability to } \\
\text { participate in } \\
\text { politics. } \\
\text { Members of the } \\
\text { Parliament are } \\
\text { increasingly } \\
\text { distant from the } \\
\text { problems of } \\
\text { ordinary people. } \\
\text { The opinions of } \\
\text { the citizens are } \\
\text { being given } \\
\text { consideration in } \\
\text { decision } \\
\text { making. } \\
\text { Politicians do } \\
\text { not care about } \\
\text { the opinions of } \\
\text { ordinary people. }\end{array}$
\end{tabular}


Q12 How much do you trust or do you not trust the following? Evaluate each party on a scale from zero to ten, where 0 is "I don't trust at all" and 10 is "I trust completely".

$\begin{array}{lllllllllll}\begin{array}{l}\text { Idon't } \\ \text { trust }\end{array} & 1 & 2 & 3 & 4 & 5 & 6 & 7 & 8 & 9 & \begin{array}{l}\text { I completely } \\ \text { comst } \\ \text { at all } 0\end{array} \\ & & & & & & & & & 10\end{array}$

\begin{tabular}{|c|}
\hline Parliament \\
\hline $\begin{array}{l}\text { Political } \\
\text { parties of } \\
\text { Finland }\end{array}$ \\
\hline $\begin{array}{l}\text { The } \\
\text { governmen } \\
\text { of Finland }\end{array}$ \\
\hline $\begin{array}{l}\text { Finnish } \\
\text { politicians }\end{array}$ \\
\hline
\end{tabular}

Q13 These days, for one reason or another, many people do not vote in elections. Did you abstain from voting in the previous parliamentary elections in spring 2019 ?

Yes

No

I don't want to say / I can’t say

Q14 Do you usually consider yourself close to any political party?

Yes

No

Q15 Which party?

The National Coalition Party (KOK)

The Social Democratic Party of Finland (SDP)

True Finns (PS)

Centre Party (KESK)

The Left Alliance (VAS)

The Green League (VIHR)

Swedish People's Party of Finland (RKP)

Christian Democrats of Finland (KD)

Some other party 
Q16 In politics, we sometimes talk about the left and the right. Using a scale where zero means most on the left and ten most on the right, where would you place yourself?

Q17 How do you feel about work-related immigration to Finland?

When answering, use a scale from one to five (1-5), where one means "very negatively," three means "neutrally," and five means "very positively."

Q18 How do you feel about Finland taking in more asylum seekers?

When answering, use a scale from one to five (1-5), where one means "very negatively," three means "neutrally," and five means "very positively."

Q19 The following is a list of some suggestions for Finland's future direction. What do you think of these proposals? To answer, use a scale from zero to ten (0-10), where zero means "very bad suggestion", five means "neither good nor bad suggestion" and ten means "very good suggestion"..

$$
\begin{array}{lllllllllll}
\begin{array}{l}
\text { Very } \\
\text { suggestion }
\end{array} & \multicolumn{4}{c}{\begin{array}{c}
\text { badNeither good } \\
\text { bad suggestion }
\end{array}} & \multicolumn{2}{c}{\begin{array}{c}
\text { norVery } \\
\text { suggestion }
\end{array}} & \text { good } \\
0 & 1 & 2 & 3 & 4 & 5 & 6 & 7 & 8 & 9 & 10
\end{array}
$$

\begin{tabular}{l} 
A multicultural Finland with a tolerant \\
attitude towards people from other countries \\
$\begin{array}{l}\text { Finland, where Christian values play a } \\
\text { greater role }\end{array}$ \\
$\begin{array}{l}\text { Finland, where the special position of } \\
\text { Finnish Swedes is taken into account }\end{array}$ \\
\hline $\begin{array}{l}\text { Finland where the rights of sexual } \\
\text { minorities are strengthened }\end{array}$ \\
\hline Finland with more expansive immigration
\end{tabular} 
Q20 People have different views on what kind of prime minister they would ideally like to lead Finland. People may also have different expectations regarding the personality traits, opinions, and behavior of the prime minister.

In the next section, we want to know more about what type of person you think would be best suited as the Prime Minister of Finland. Next, we present various descriptions of potential prime ministerial candidates. The descriptions contain information about the backgrounds and political opinions of different individuals.

You will be shown six pairs of potential prime ministerial candidates. We ask you to choose after each pair the candidate that you think would be best suited for the Prime Minister of Finland.

Read the description of each candidate carefully before making your decision..

Q21 (1/6) Choose your preferred Prime Minister-candidate from the options below: [Conjoint pairs]

Q22 Would you vote for this candidate in elections?

Yes

Note

Q23 (2/6) Choose your preferred Prime Minister-candidate from the options below: [Conjoint pairs]

Q24 Would you vote for this candidate in elections?

Yes

No

Q25 (3/6) Choose your preferred Prime Minister-candidate from the options below:

[Conjoint pairs]

Q26 Would you vote for this candidate in elections?

Yes

No 
Q27 (4/6) Choose your preferred Prime Minister-candidate from the options below: [Conjoint pairs]

Q28 Would you vote for this candidate in elections?

Yes

No

Q29 (5/6) Choose your preferred Prime Minister-candidate from the options below: [Conjoint pairs]

Q30 Would you vote for this candidate in elections?

Yes

No

Q31 (6/6) Choose your preferred Prime Minister-candidate from the options below:

[Conjoint pairs]

Q32 Would you vote for this candidate in elections?

Yes

No

Q33

Finally, we would like to ask about your attitude to democracy as a political system.

Q34 What do you think of the following statement(s)? 


$\begin{aligned} & \text { Compeletely } \\ & \text { disagree }\end{aligned} \quad$ Somewhat disagree $\begin{aligned} & \text { Agree to some } \\ & \text { extent }\end{aligned}$

\begin{abstract}
Democracy may have its problems, but it is better than other forms of government.
\end{abstract}

Democracy is not an effective form of government, and it would be better for Finland to be led by a strong leader who does not have to care about elections.

It is important that there is free and politically independent media in Finland.

Citizens' right to political participation should not be restricted.

There should be no political pressure on the judiciary.

Politicians should treat each other with respect, despite political differences. 